\title{
ENGINEERING ARBITRATION \& RESOLVING DISPUTES FOR CONSTRUCTION CONTRACTS
}

\author{
Omer A.Elaziz Maher*1, Khaled M. Khorshid ${ }^{2}$ and Magdi M. Kasem ${ }^{2}$ \\ ${ }^{1}$ Nasr City Company for Housing and Development, Nasr City, Cairo, Egypt. \\ ${ }^{2}$ Architecture Department, Faculty of Engineering, Al-Azhar University,Cairo, Egypt. \\ *Corresponding Author Email: eng_omar2006@yahoo.com
}

\section{ABSTRACT}

Generally, most of contracts \& especially commercial contracts are being agreed upon and executed with no difficulties to be mentioned, and in case of any difficulties appear in the contracts, they are resolved by the parties after subjective and continuous discussion, but contractual parties may not reach suitable agreement therefore disputes are raised and need to be resolved. Generally, there are four types to resolve disputes that may arise between contractual parties :-Direct negotiation between contract parties, Resort to an alternative solution such as mediation, conciliation \& experience, Arbitration, Resolving disputes by national courts. There must be reference to some types of disputes that cannot be resolved only by national courts as it may be related to political and legal aspects and state sovereignty and the judicial system. As any dispute arises from defining the responsible party for the collapse of a standing building and causes damages or victims and lose of human lives that cannot be judged by arbitration as only the national judicial system has the right to final judgment in such matters related to criminal or Penal matters. Statistics have shown that the rate of disputes is increasing specially the international disputes and refer many of them for arbitration. To answers those two questions, it's important to understand the nature of construction contracts firstly of legal aspects and secondly representing the methods of resolving such disputes either by arbitration or judicial courts and the reasons behind the high rate of such disputes especially on international level, thirdly studying arbitration as a method of resolving disputes. Theoretical study: knowledge of construction contracts.

Deductive study: the methods to resolve disputes by judicial system or engineering arbitration. Application studies: arbitration case

\section{KEY WORDS: Engineering Arbitration, Resolving Disputes, Construction Contracts, Egyptian Arbitration Law, FIDIC}

$$
\begin{aligned}
& \text { التحكيم الهندسى فى فض نزاعات عقود المقاولات }
\end{aligned}
$$

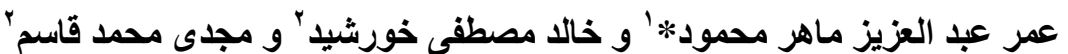

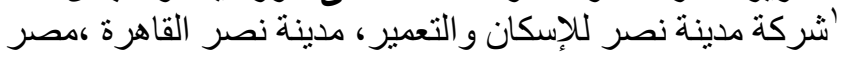

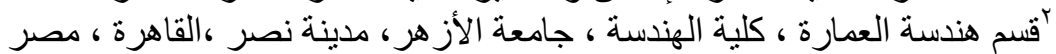

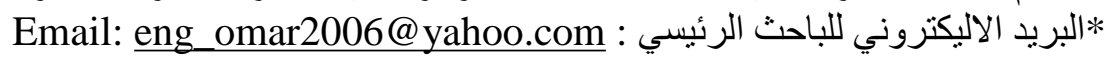

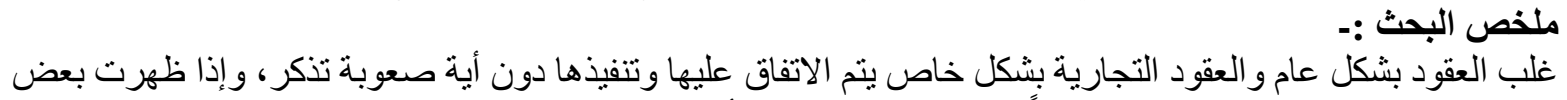

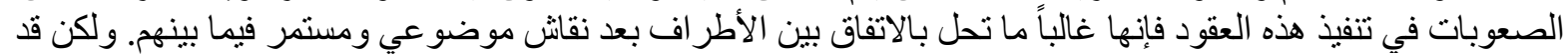

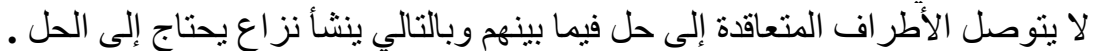

$$
\begin{aligned}
& \text { ـ و بشكل عام يوجد أربعة أنواع لحل الخلافات التي يمكن أن تنشأ بين الأطر افت المتعاقدة : }
\end{aligned}
$$


إجر اء مفاوضات مباثرة بين المتعاقدين ، اللجو ء إلى أحد ا لحلول البديلة لحل النزاعات مثل الوساطة و التوفيق والخبرة

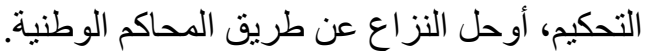

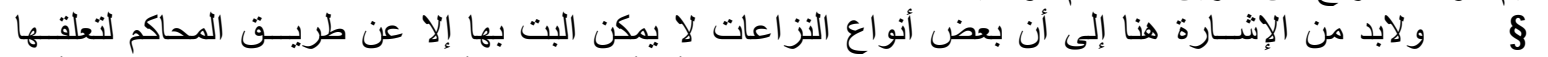

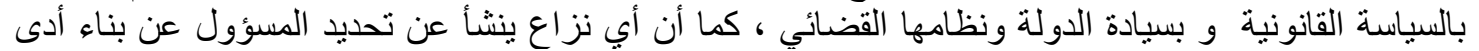

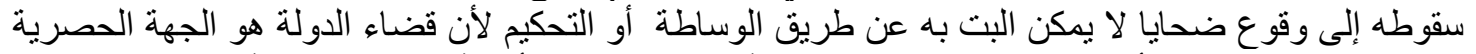

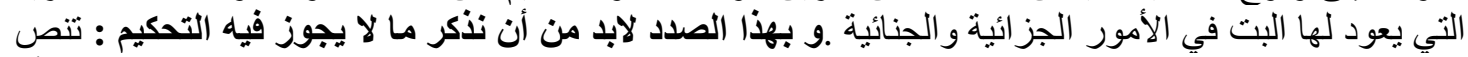

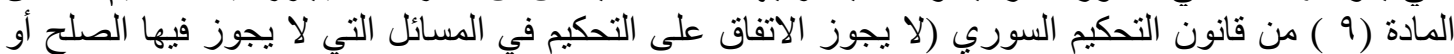

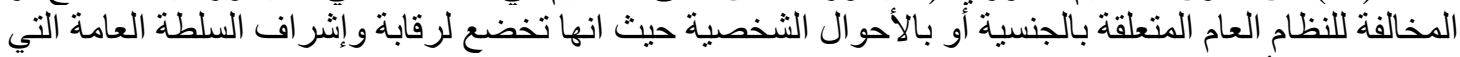

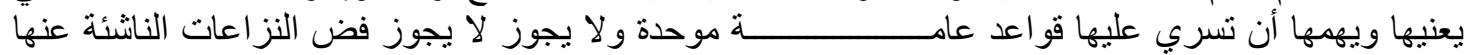

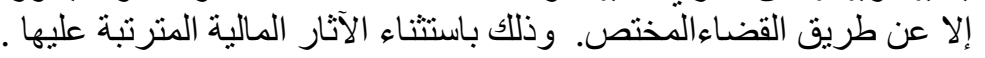

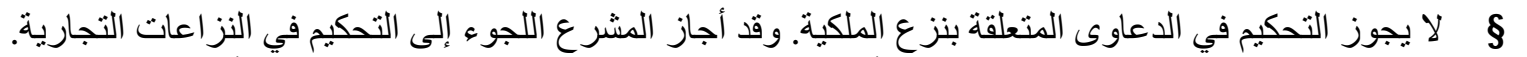

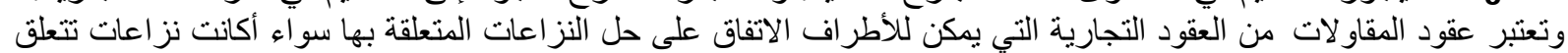
بتفسير ها أو تنفيذها أو إنهائها أو نهايتها.

وقد أظهرت الإحصائيات تزايد نسبة هذه النزاعات وخاصة الدولية منها وإحالة الكثير منها إلى التحكيم ، حيث اظهرت العيثة العديد من

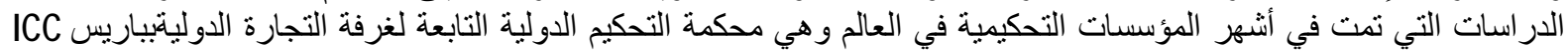

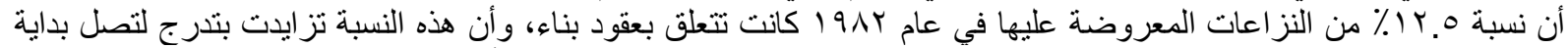

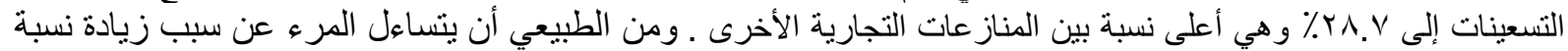

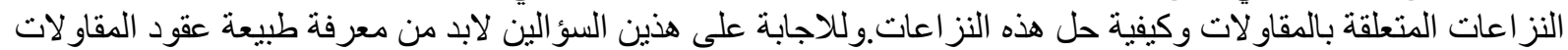

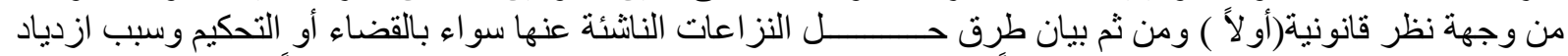

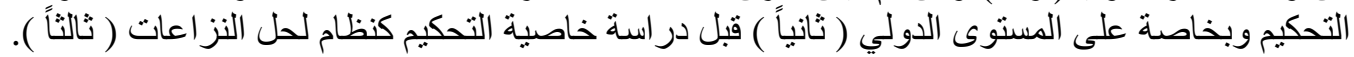

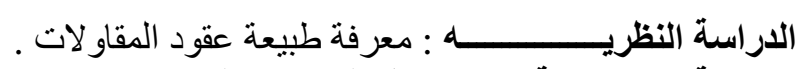

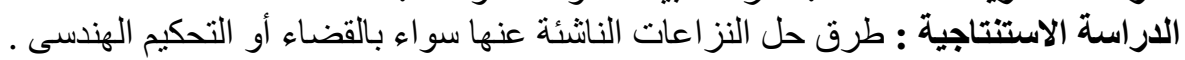

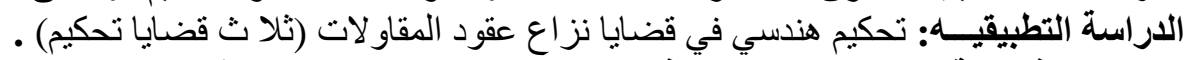

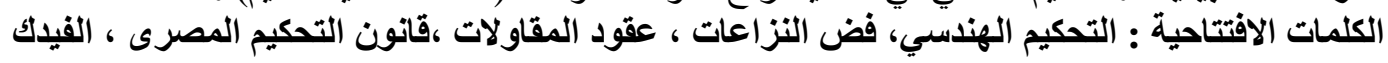

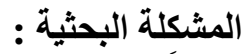

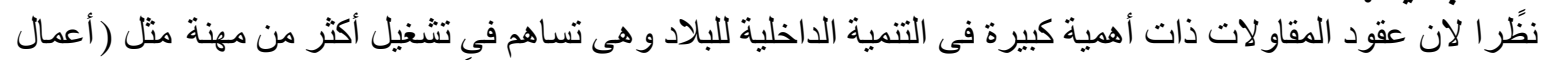

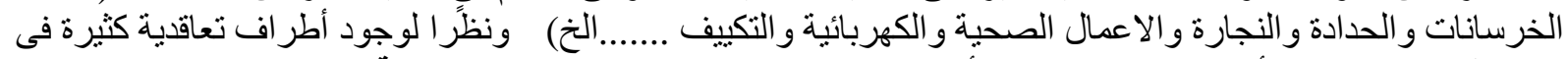

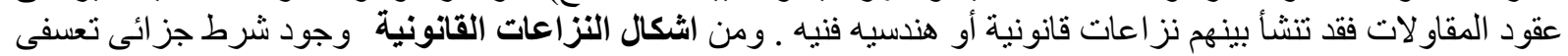

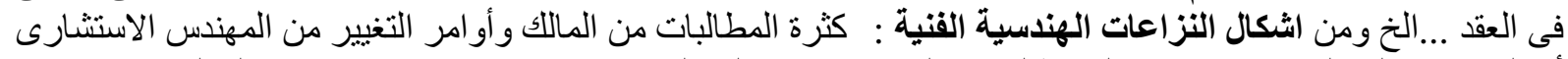

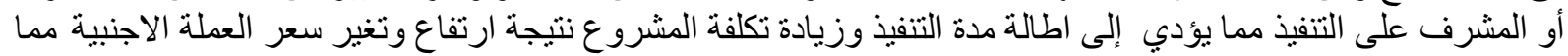

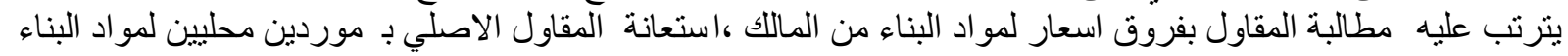

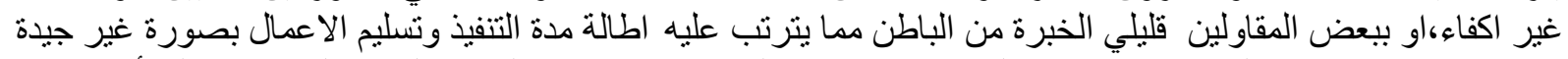

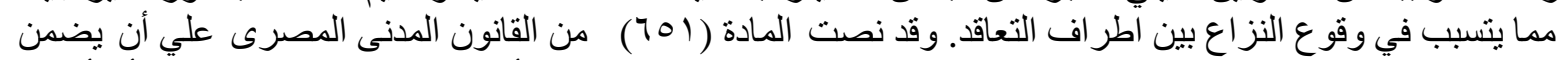

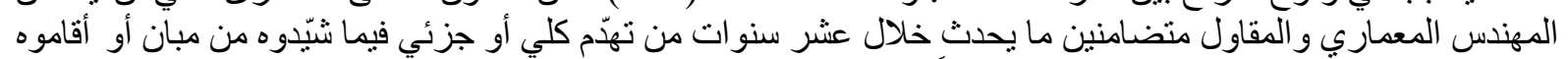

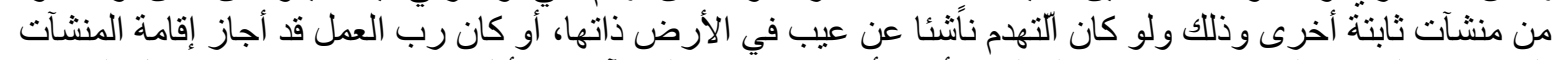

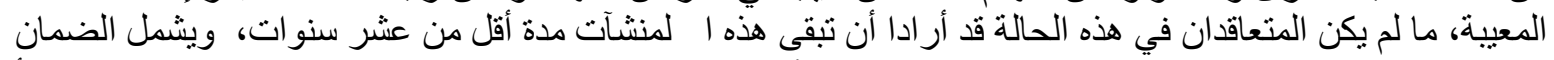

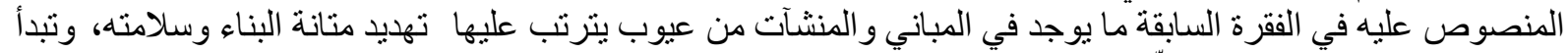

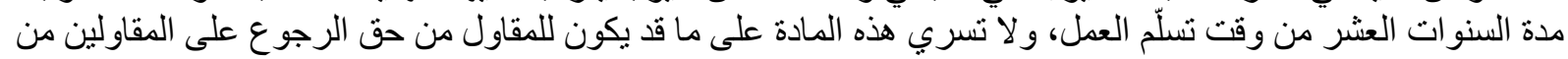
الباطن. 


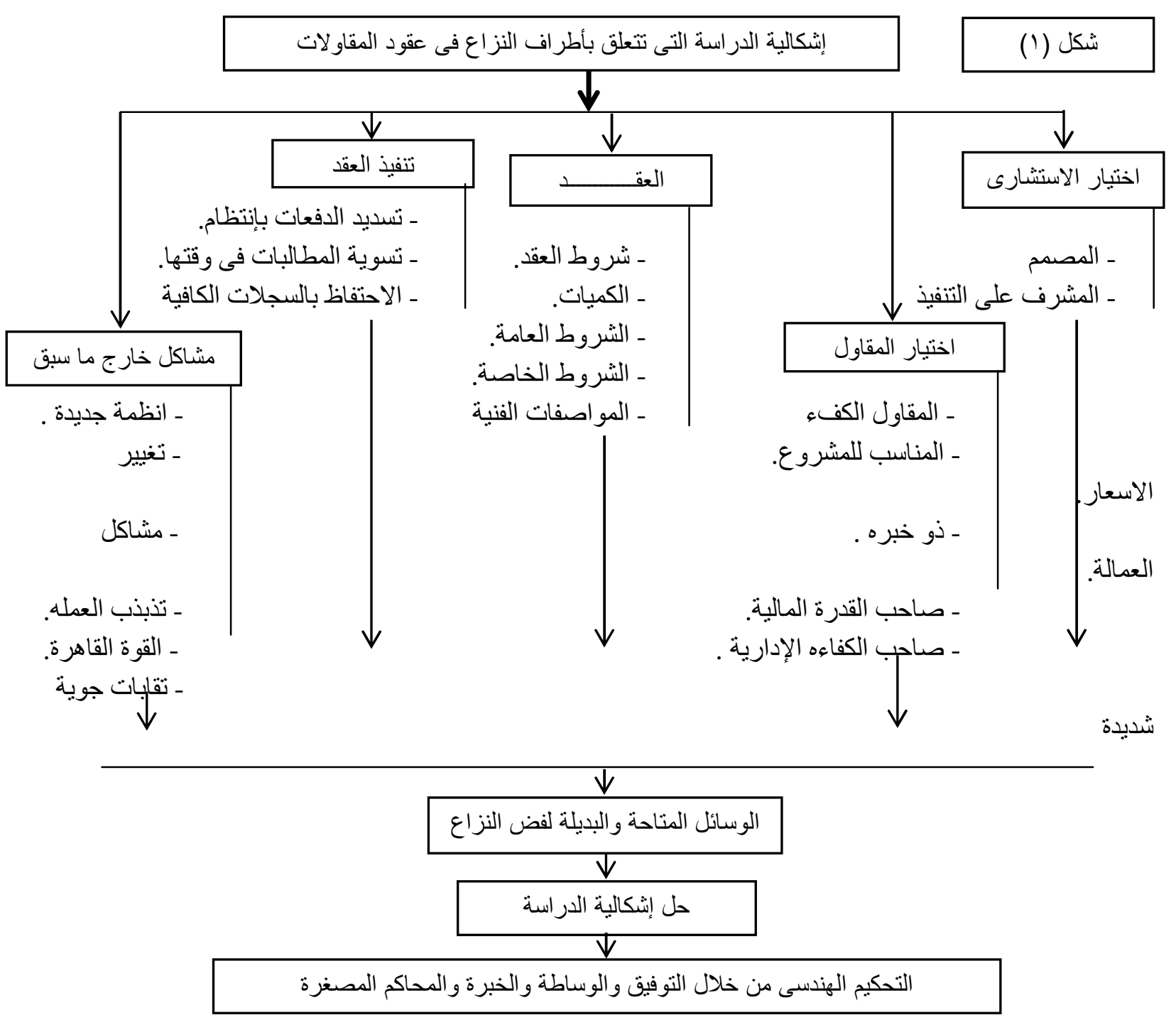

* فرضية البحث :- التنسيمى هو السبيل العاجل لفض النزاع بين الأطر اف المتناز عة فى عقود المقاو لات فى المشاريع المختلفة

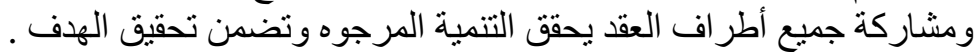

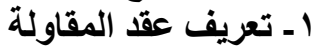
عرف عقد المقاولة على الوجها الآتي: "المقاولة عقد يتعهد بمقتضاه أحد المتعاقدين أن يصنع شينًا أو أن يؤدي عملاً لقاء

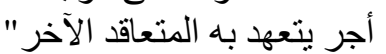

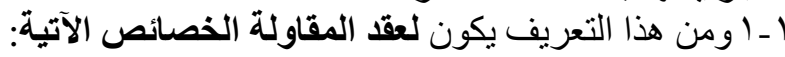

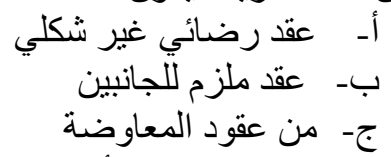
يقع التر اضي فيه على عنصرين:أحدهما الثيء المطلوب أو العمل المطلوب من المقاول وثانيهما الأجر الذي يتعهد به رب

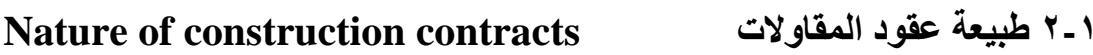

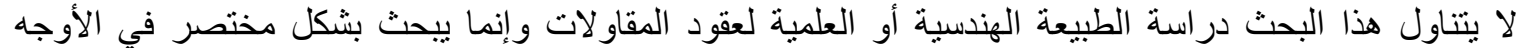

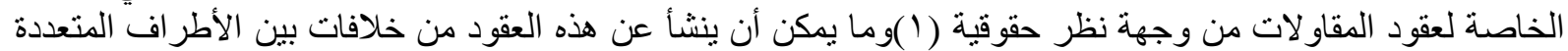

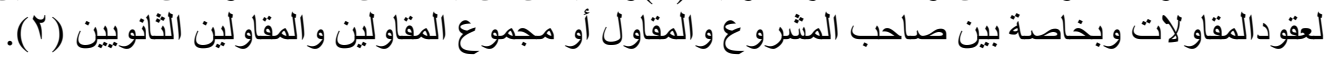




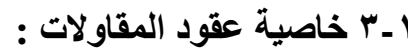

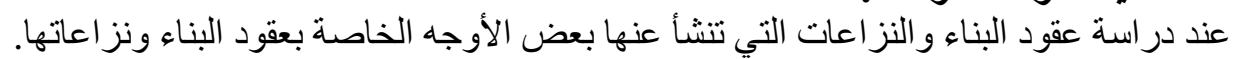

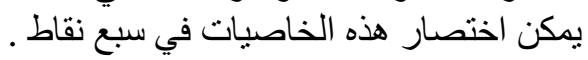

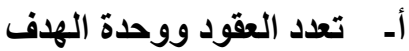

أول هذه الخاصيات هو أن مشرود الفودود البناء ينطلب عدد كبير من المتعاقدين واختصاصات مختلفة من الأعمال غالباً مايتم

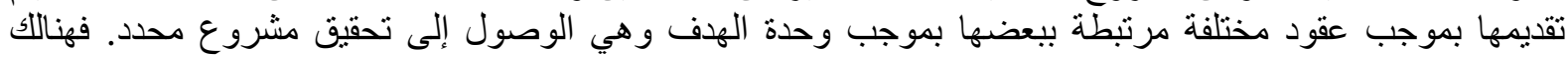

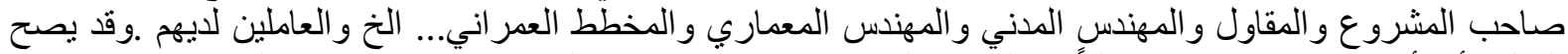

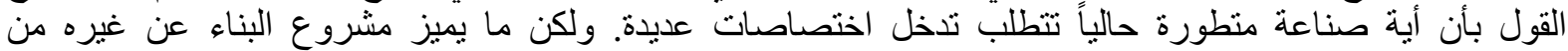

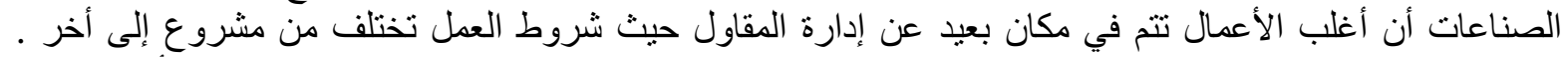

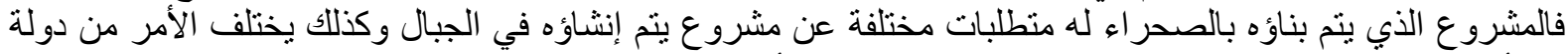

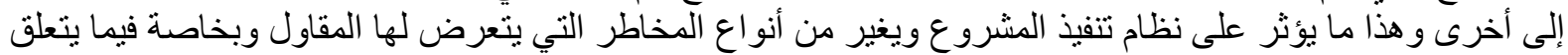

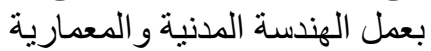

ب- تعدد الوثائق والرسومات والمعارية والمخططات :

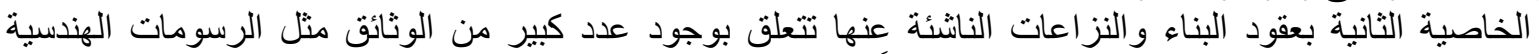

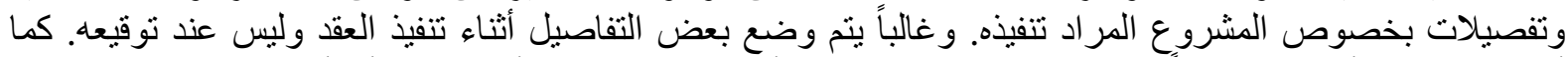

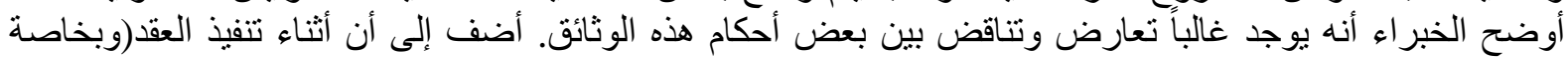

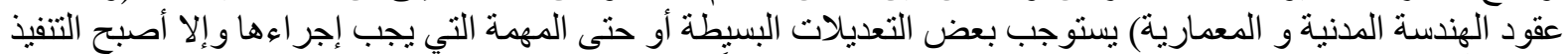

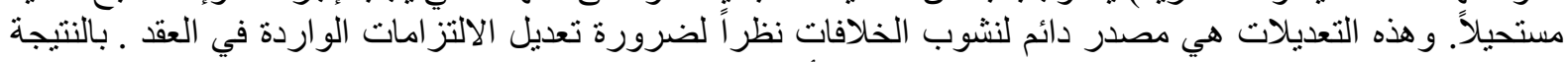
فإن وجود عدد كبير من الوثائق في عقود البناء هو مصدر أكيد لنشوء النزاعات النيات المستقبلية بين المتعاقدين.

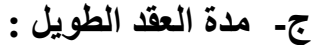

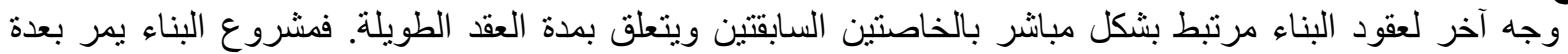

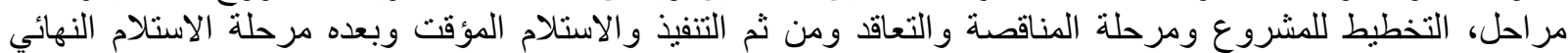

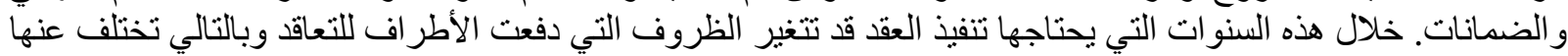

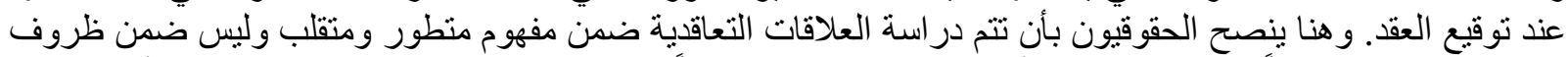

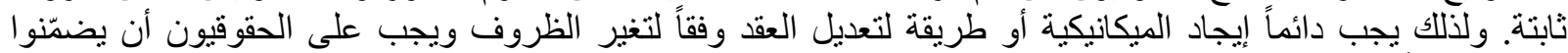

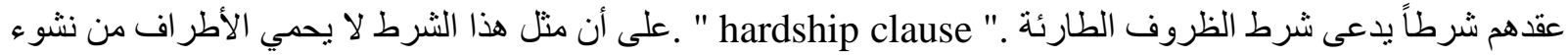

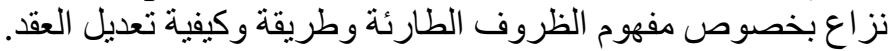

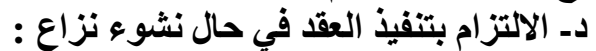

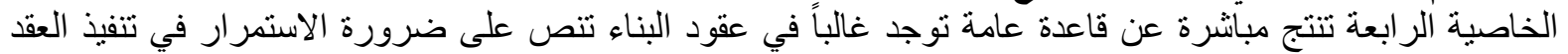

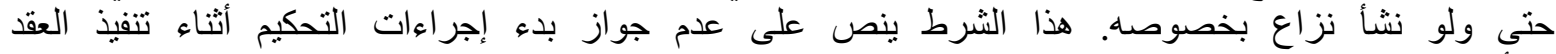

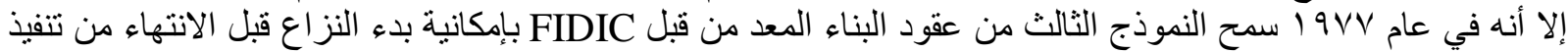

العقد.

هـ - وجود نماذج تعاقية معدة مسبقاً :

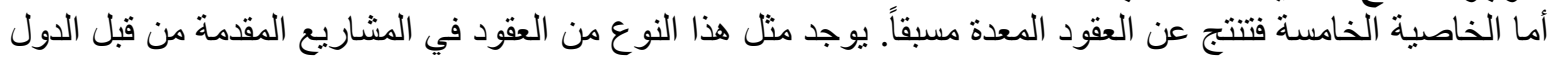

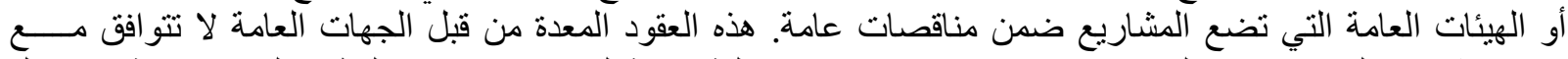

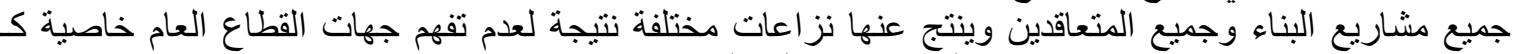

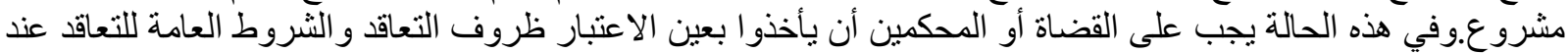

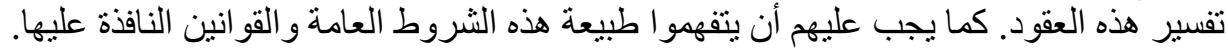

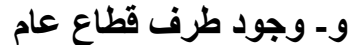

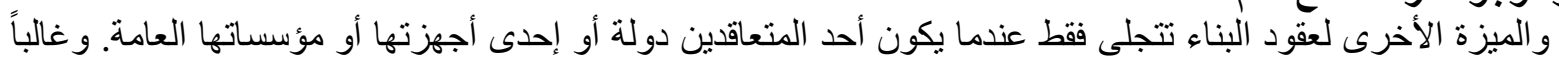

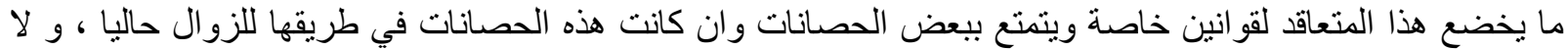

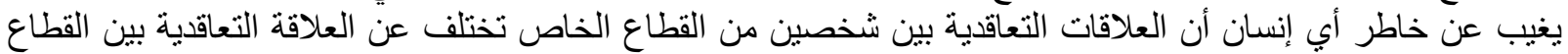

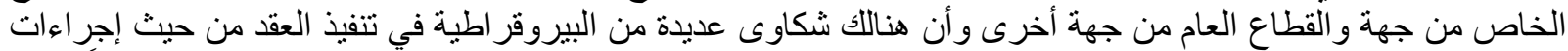

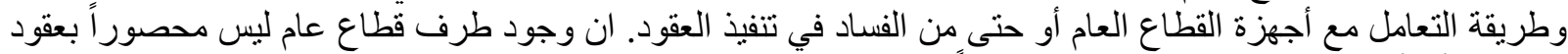

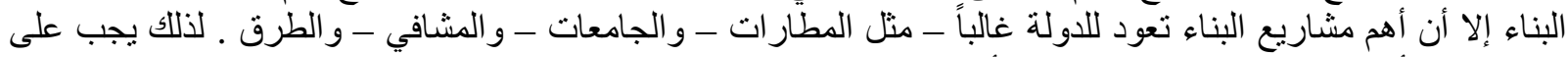

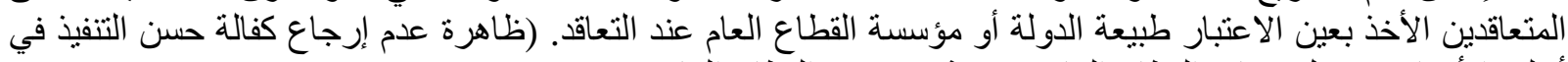
أغلب الأحيان من قبل هيئات القطاع العام معروفة في عقود القطاع العام العام). 
ز - عقود المقاولات عبارة عن أرض خصبة لنشوء الخلافات :

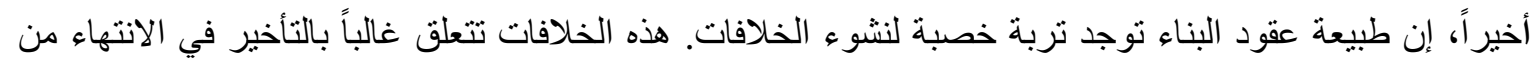

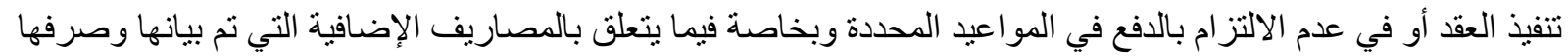

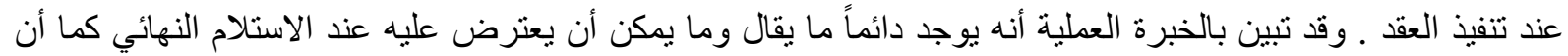

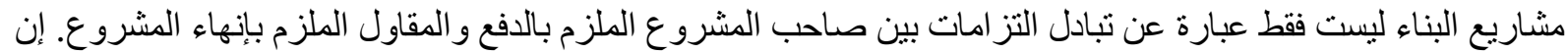

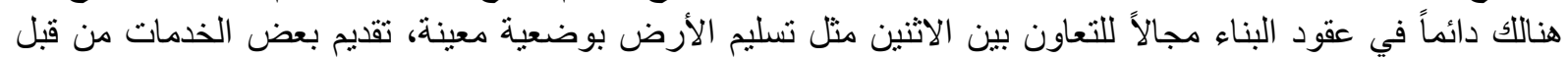

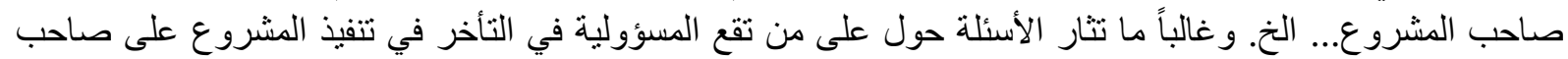

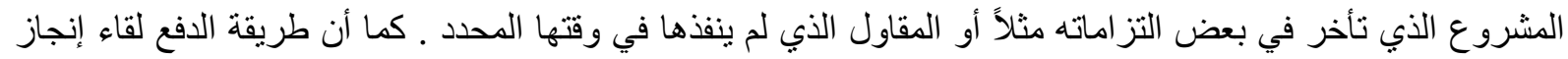

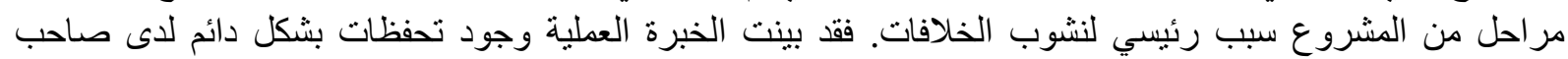

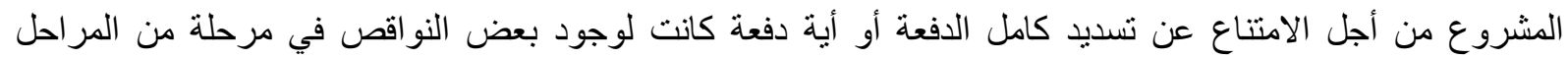

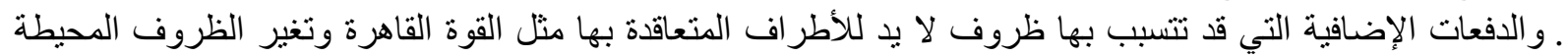

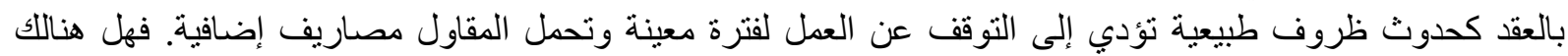

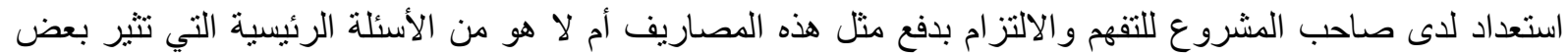

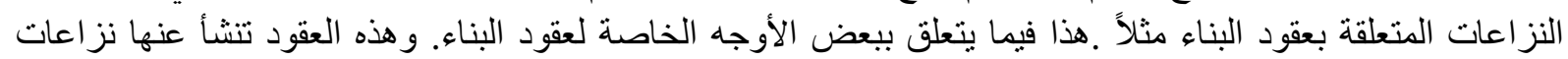

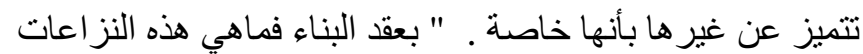

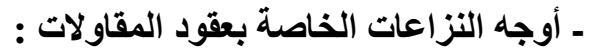

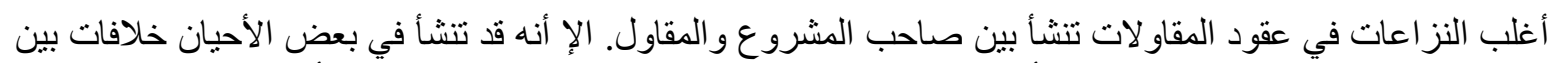

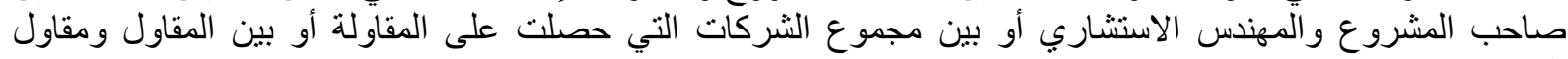

أـ النزاعات الممكن وقوعها بين صاحب المشروع و المقاول :

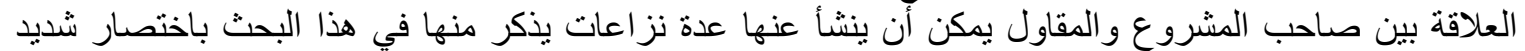

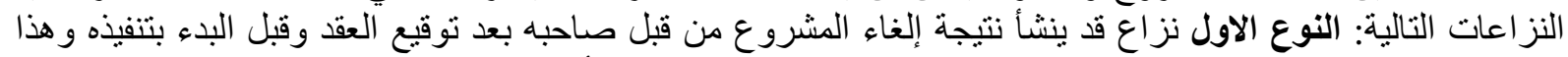

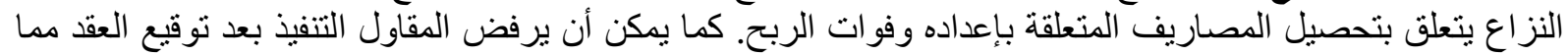

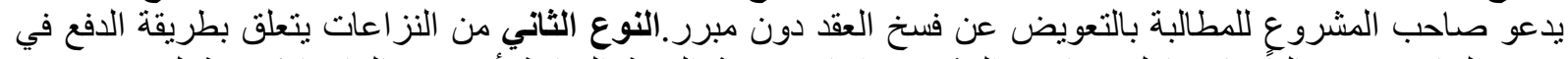

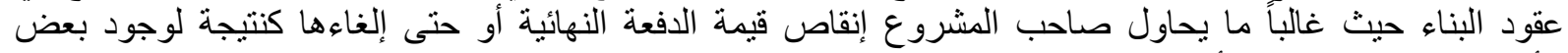

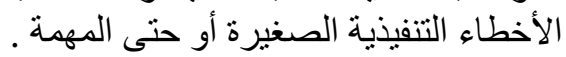

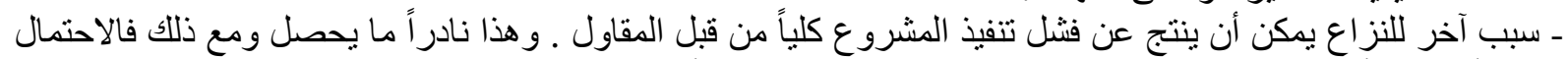

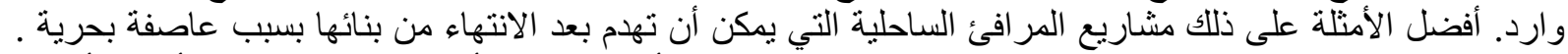

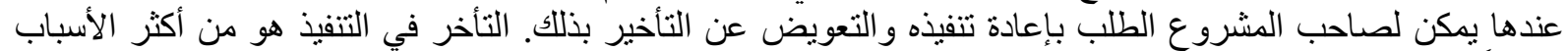

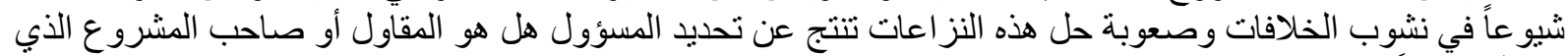

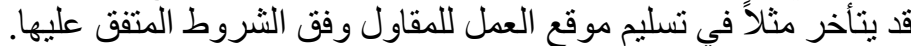

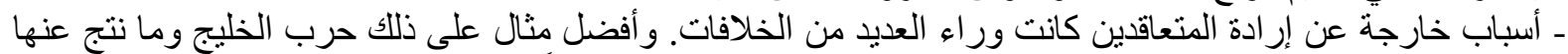

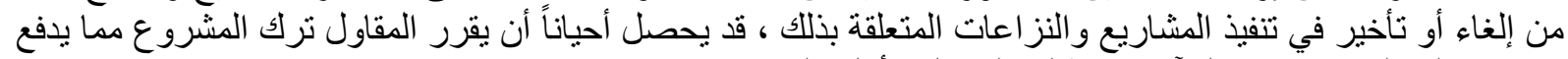

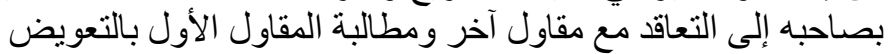

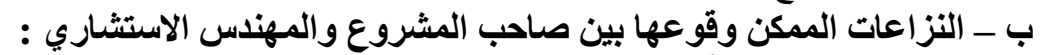

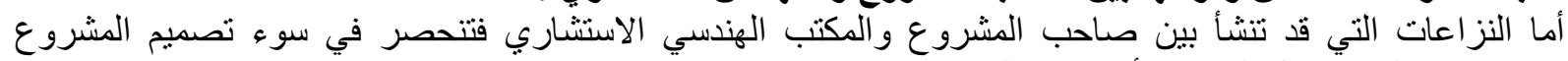

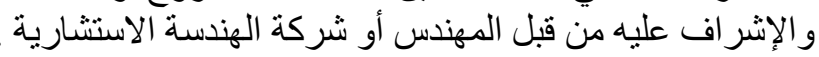

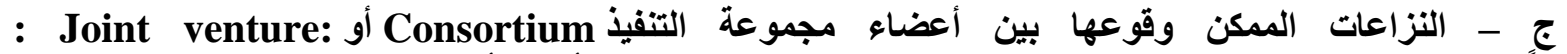

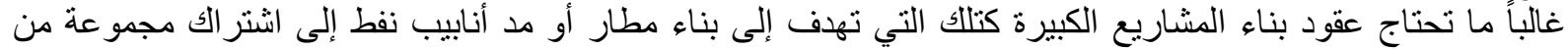

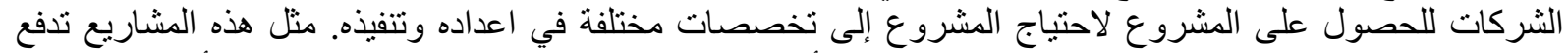

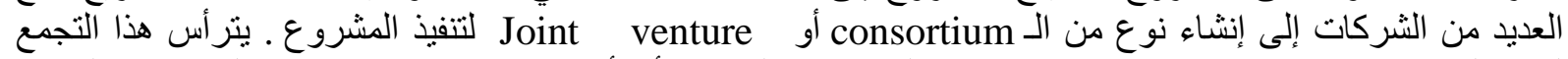

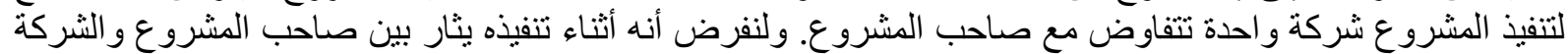

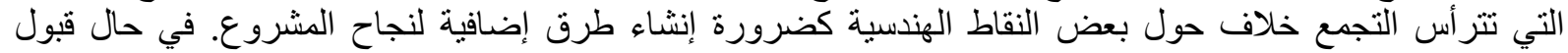

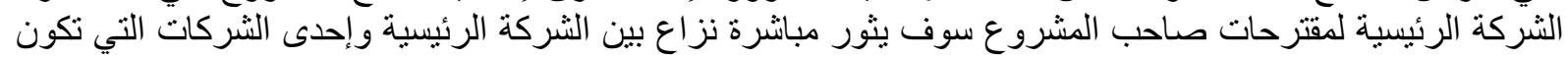

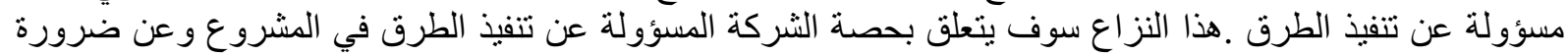

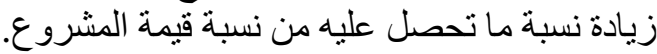
دـ النزاعات الممكن وقوعها بين المقاول الرئيسي ومقاول الباطن : 
في المشاريع الكبيرة، كتلك التي تتعلق ببناء فندق خمسة نجوم مثنلاً، قد يوجد ما يزيد عن عشرات المقاولين من الباطن

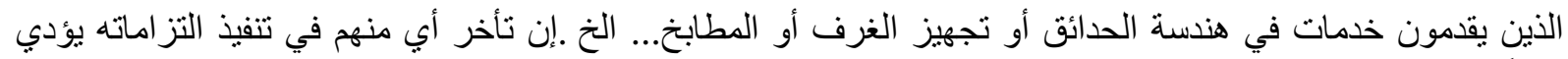

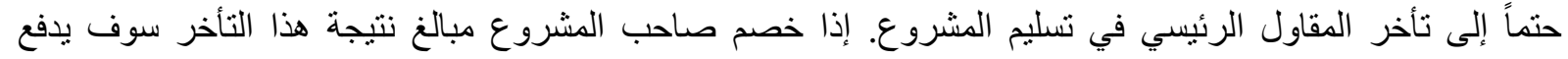

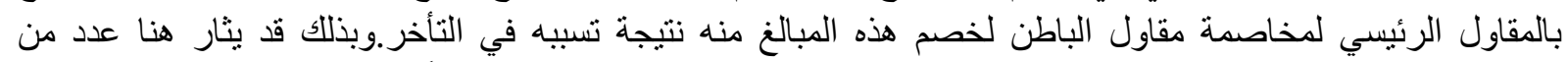

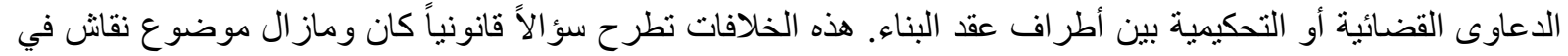

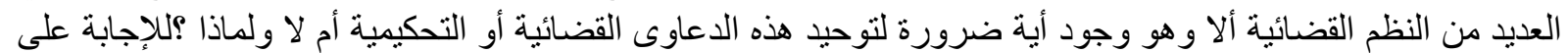

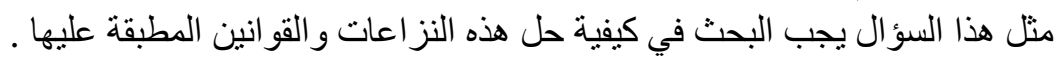

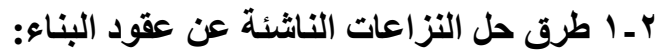

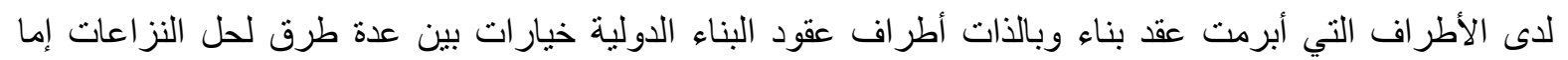

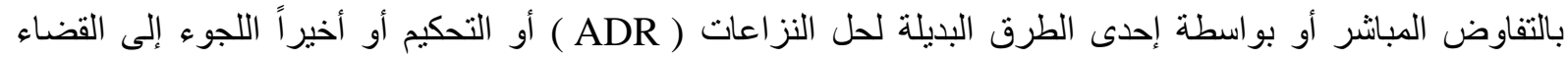

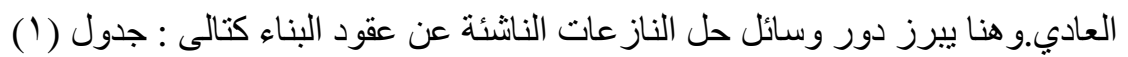

\begin{tabular}{|c|c|c|c|}
\hline التحكيم & التوفيق & الوساطة & البند \\
\hline ملزم & غير ملزم & غير ملزم & إلزامية القرار \\
\hline مجتمعين & مجتمعين أو منفردين & مجتمعين أو منفردين & الإجراءات \\
\hline قر ار ملزم & قرار غير ملزم & لا يوجد قرار & القرار \\
\hline قد تكون غير مرضية & مرضية للجميع & مرضية للجميع & النتائج \\
\hline قليلة & عالية & عالية & الاستجابة \\
\hline قد يكون مكلفا & غير مكلف & أقل تكلفة & التكلفة \\
\hline تحافظ (1) & قد لا تحافظ & تحافظ & العلاقات الاجتماعية \\
\hline
\end{tabular}

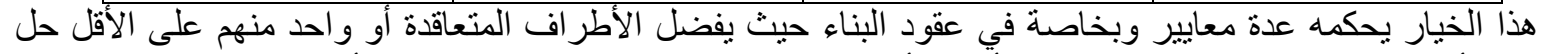

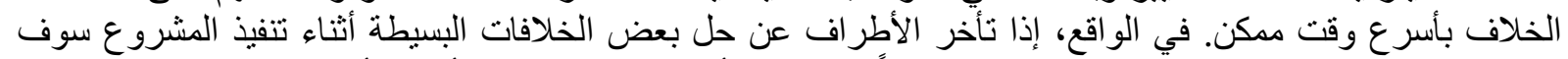

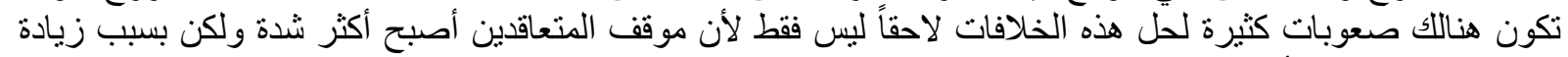

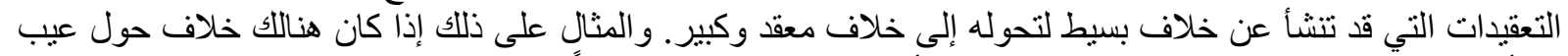

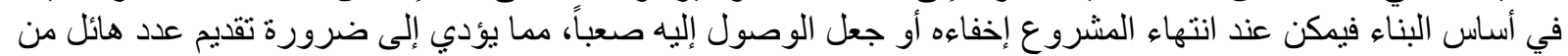

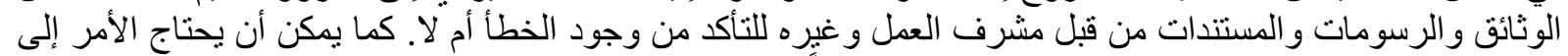

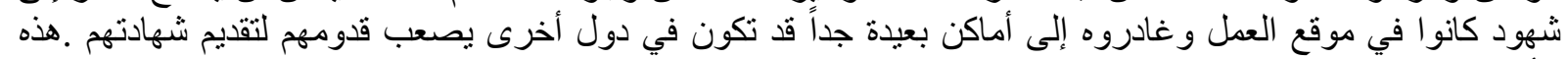

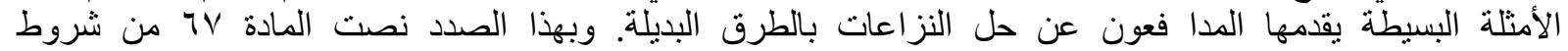

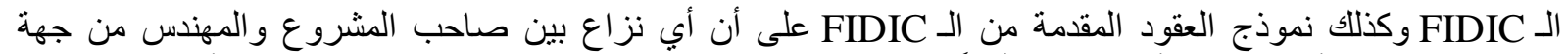

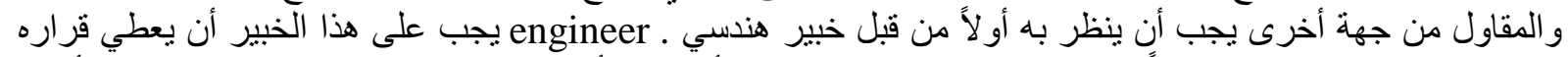

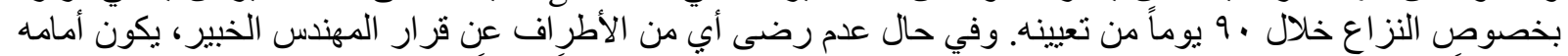

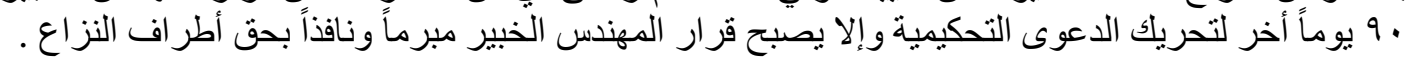

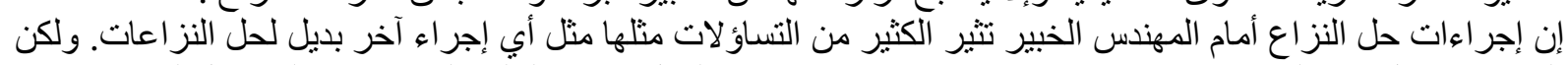

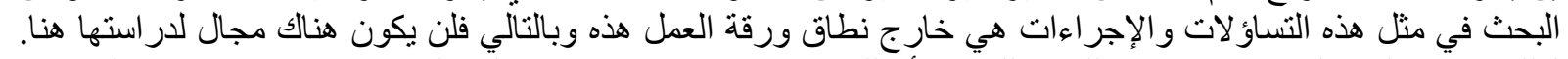

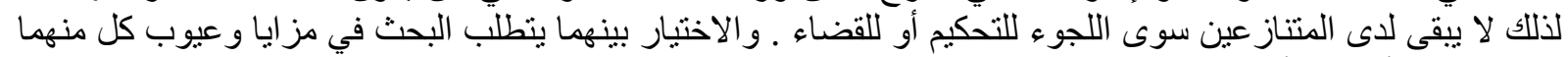

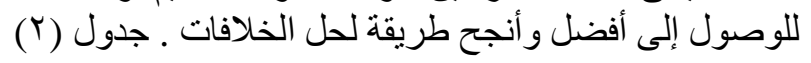




\begin{tabular}{|c|c|c|}
\hline \multicolumn{3}{|c|}{ مزايا وعيوب كل نظام } \\
\hline التحكيم & القضاء & البند \\
\hline 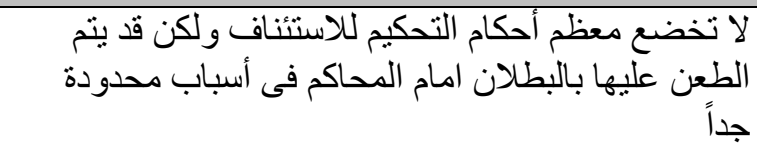 & تختضع أحكام القضاء للاستئناف و أنو اع اع من & نهاية الحكم \\
\hline 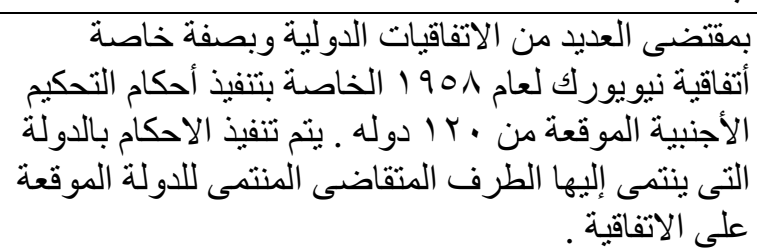 & 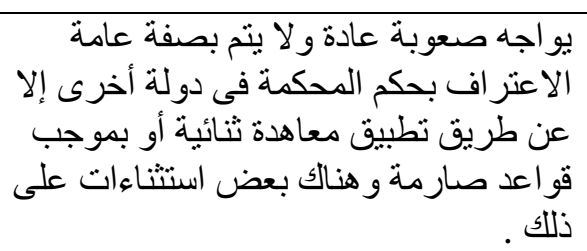 & الاعتراف الدولى \\
\hline 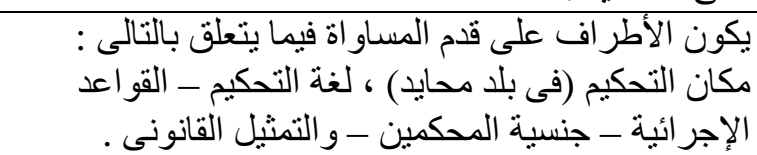 & 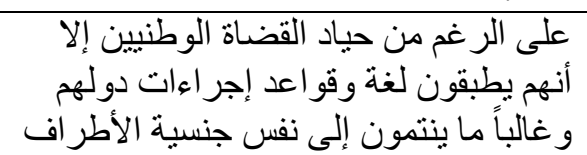 & 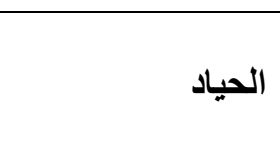 \\
\hline 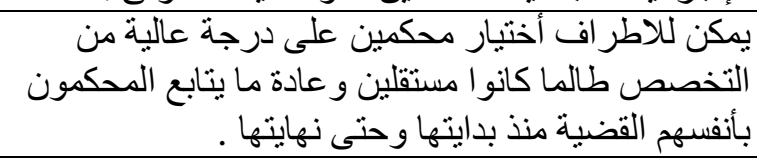 & ويتعد القضاة الذين يتابعون القضينية وقد يختلف & والتختصعة الثخصية \\
\hline 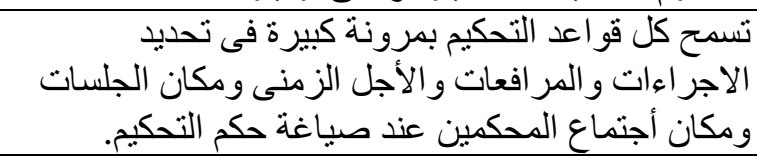 & تتقيد محاكم الدولة بشدة القو اعد الإجر ائية . & المرونة \\
\hline 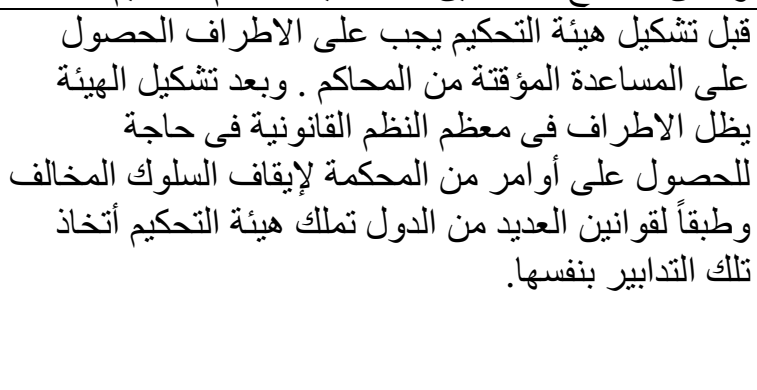 & 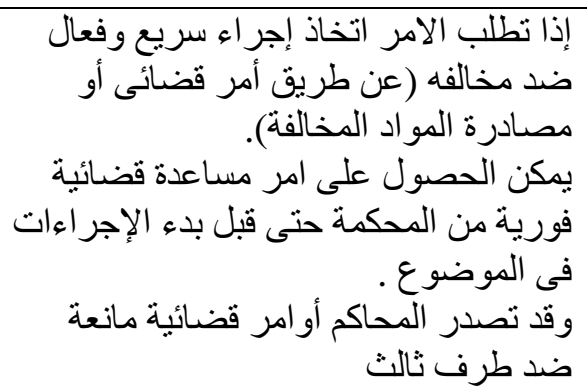 & التدابير المؤقتة \\
\hline 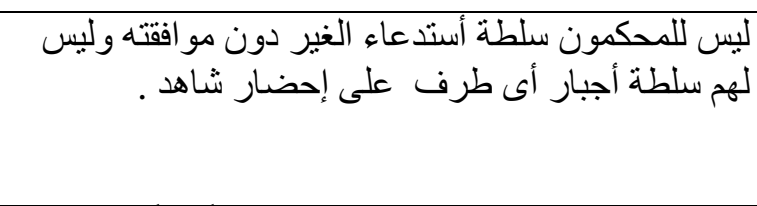 & 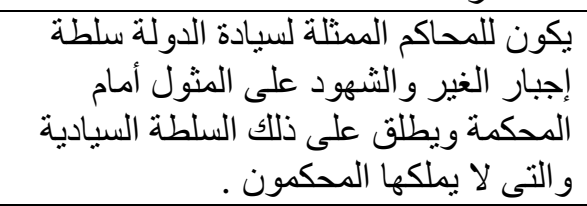 & الشهود \\
\hline 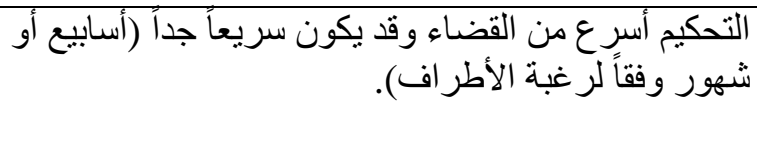 & 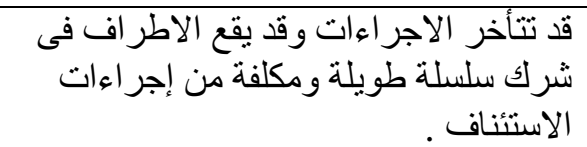 & السرعة \\
\hline 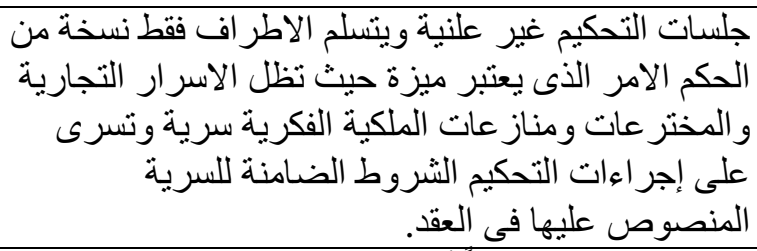 & جلسات المحاكم و النطق بالحكم علنية & 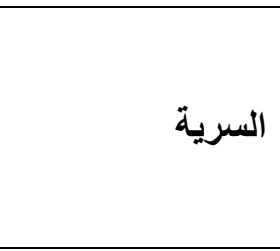 \\
\hline 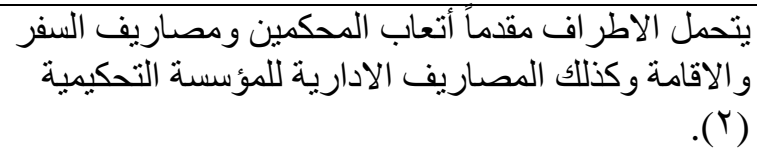 & 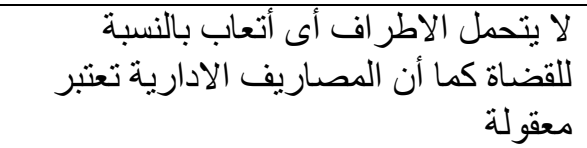 & المصاريف \\
\hline
\end{tabular}

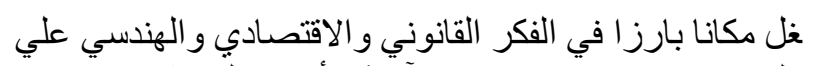

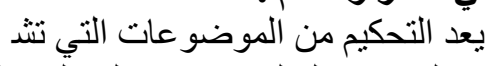

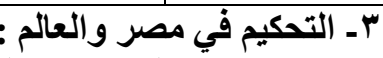

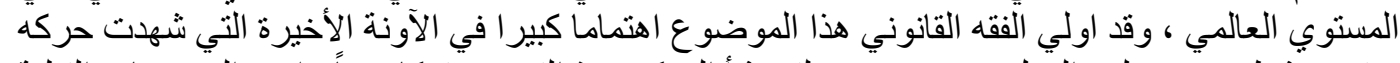

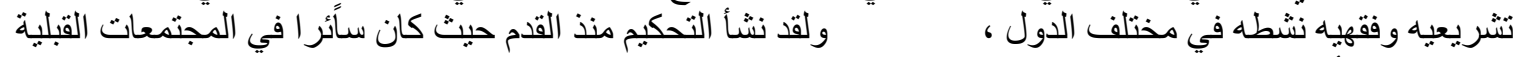
باعتباره الأداة الفردية للتسوية الودية للمناز عات عن طريق الغير ، ولقد كان عرفا في المجتمعات الفرعونية 


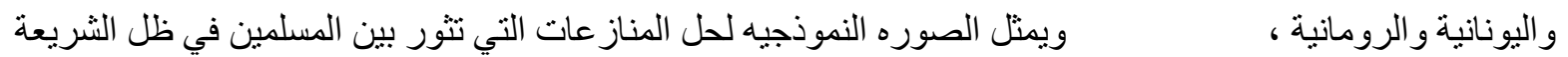

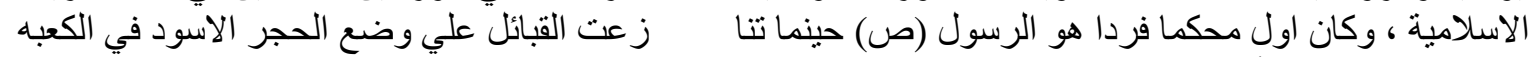

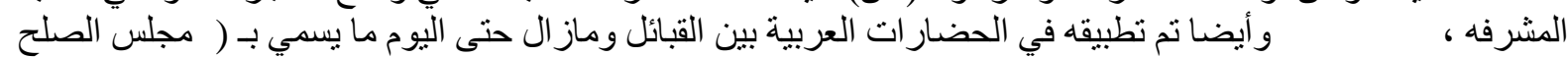

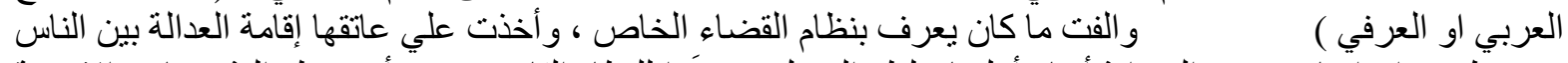

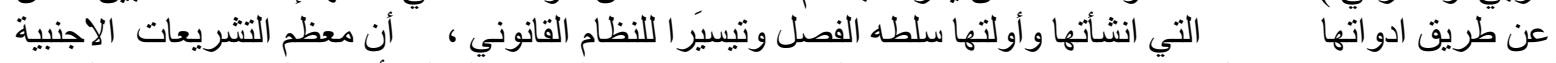

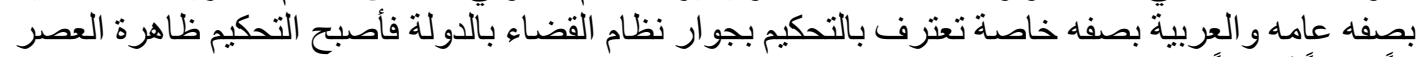

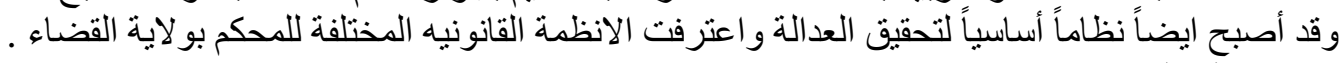

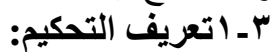

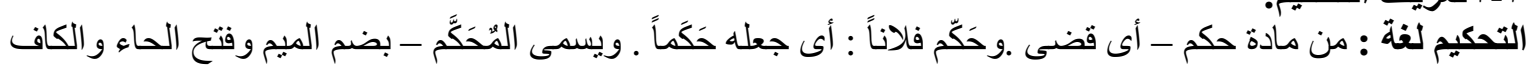
المشددة

اصطلاحا : هو تولية الخصمين حاكماً يحكم بينهما. تعريف التحكيم في الاصطلاح القانوني :-

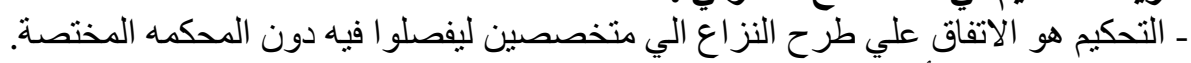

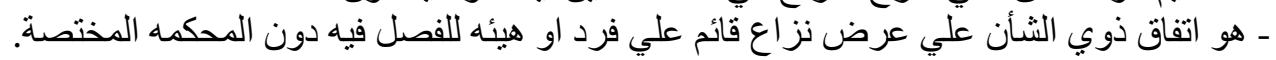

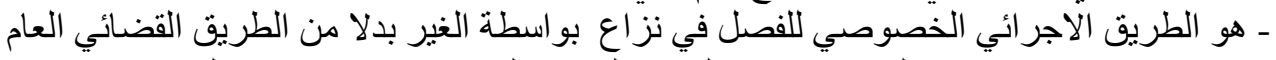

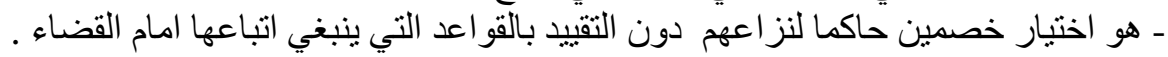

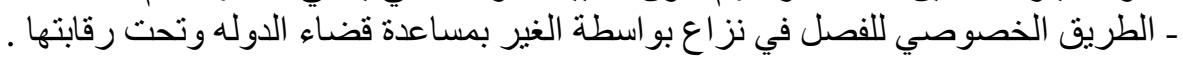
2-3مشروعية التحكيم :

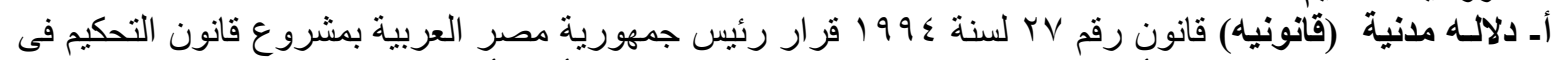

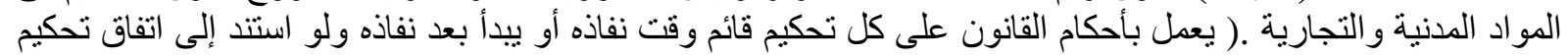

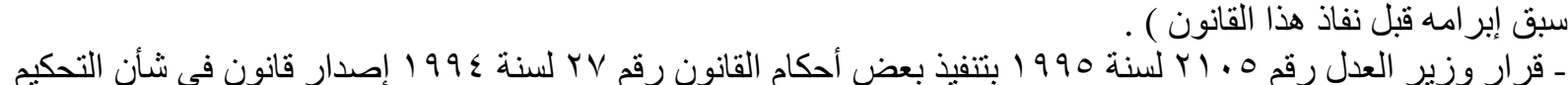

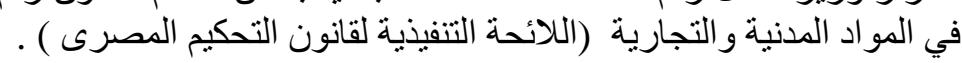

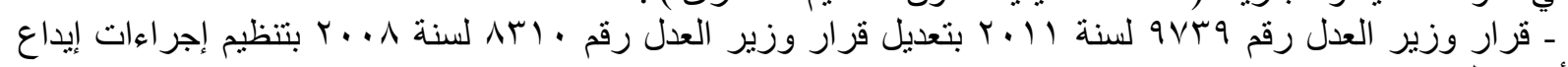

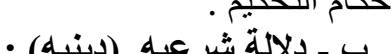

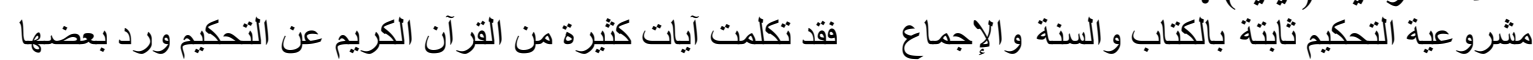

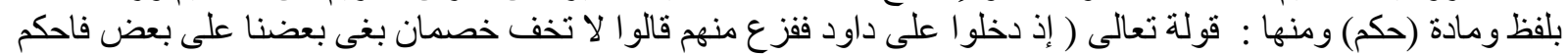

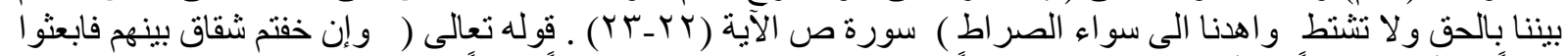

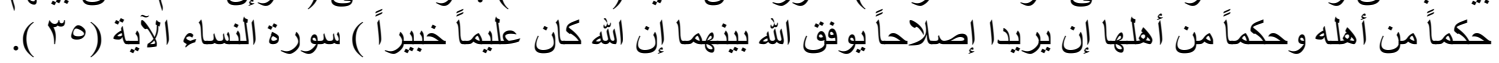

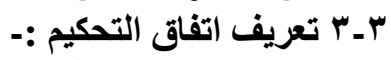

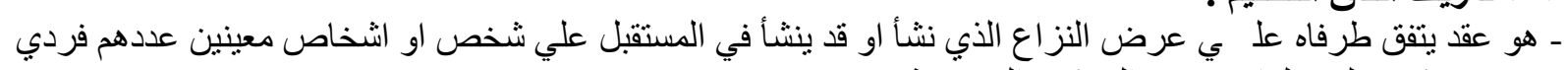

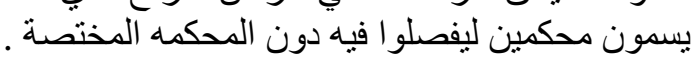

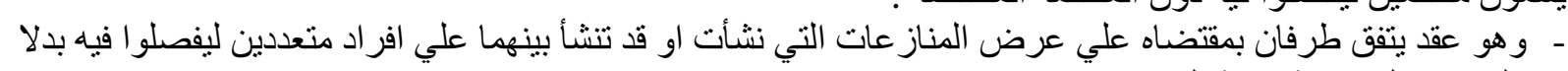

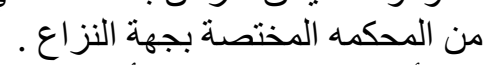

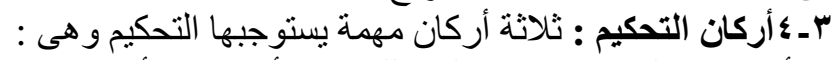

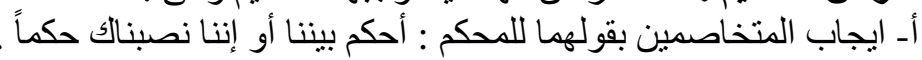

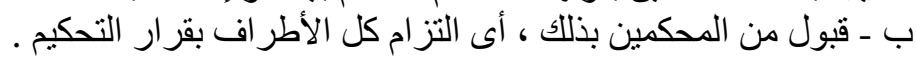

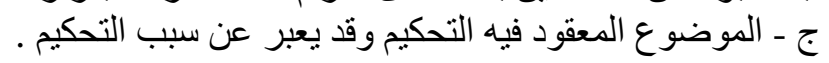

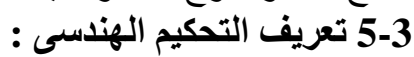

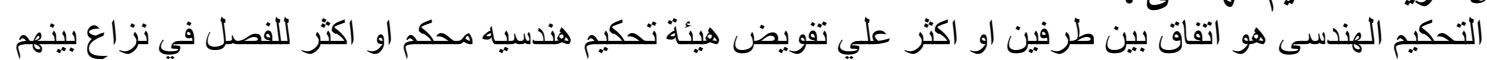

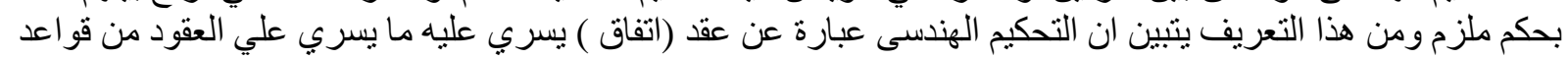

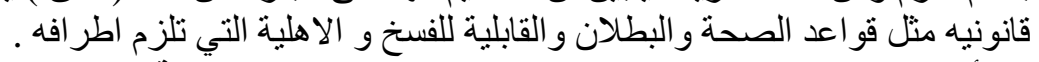

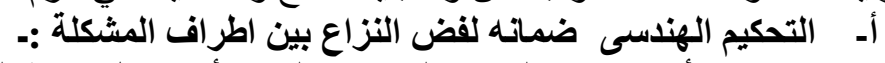

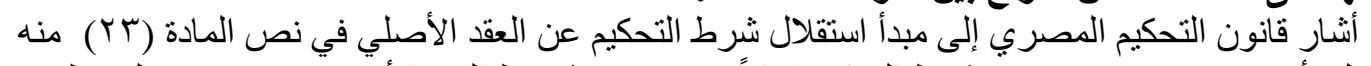

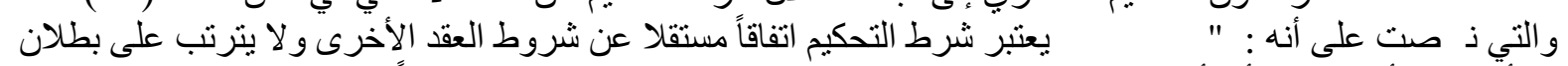

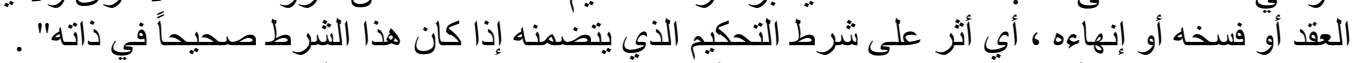

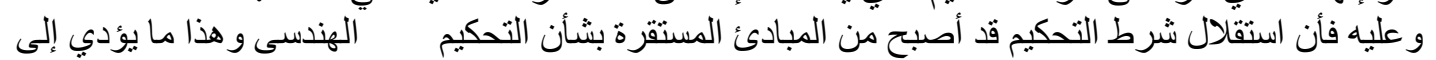

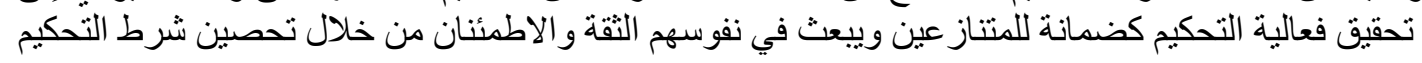


من كل أسباب البطلان التي تمس قرار التحكيم وهذا ما يجعل من التحكيم وسيلة فعالة لحسم المناز عات الناشئة

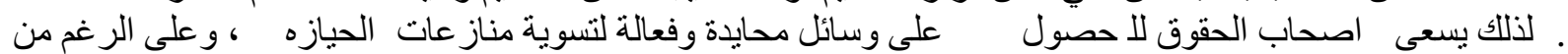

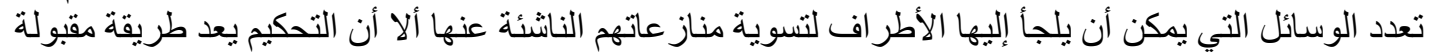

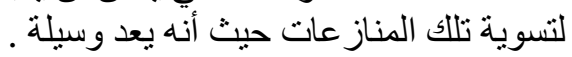

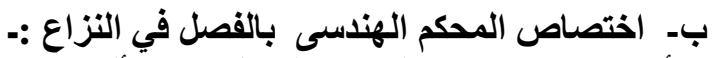

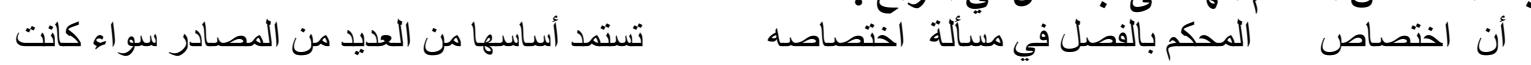

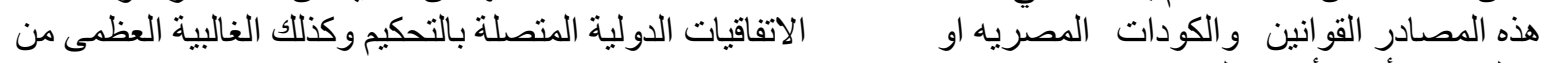

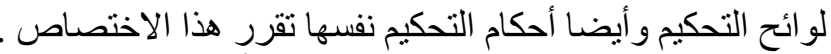

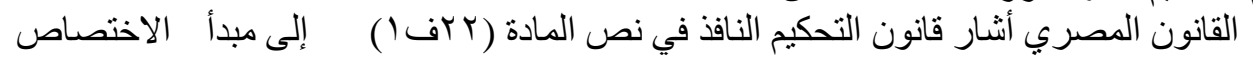

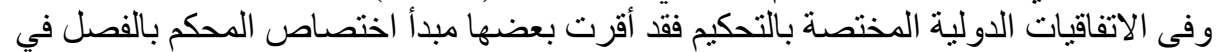

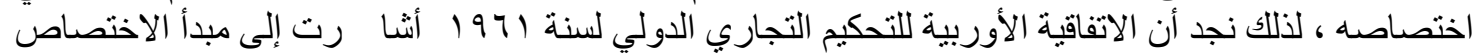

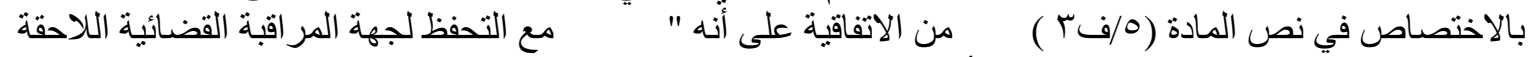

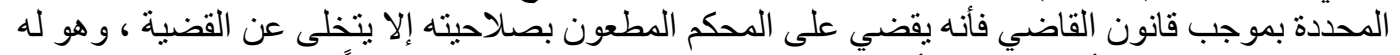

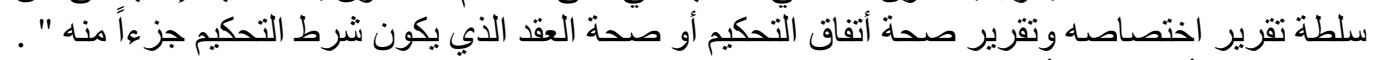

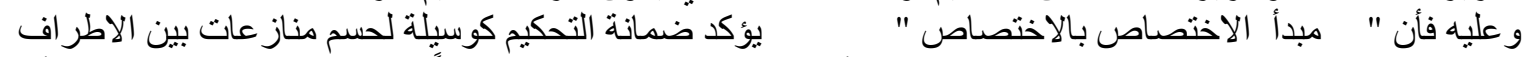

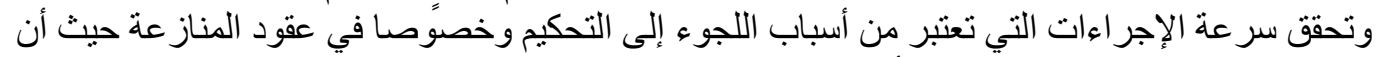

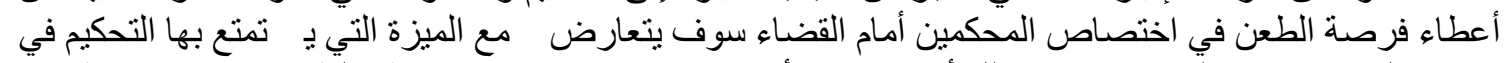

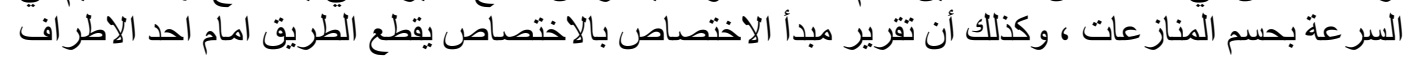

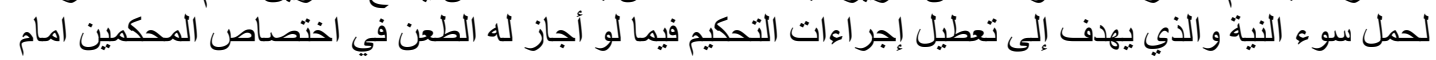

ويمكن ايجاز تلك المبادئ التي يقوم عليها نظام التحكيم الهندسى فى التالى :- شكل (r)

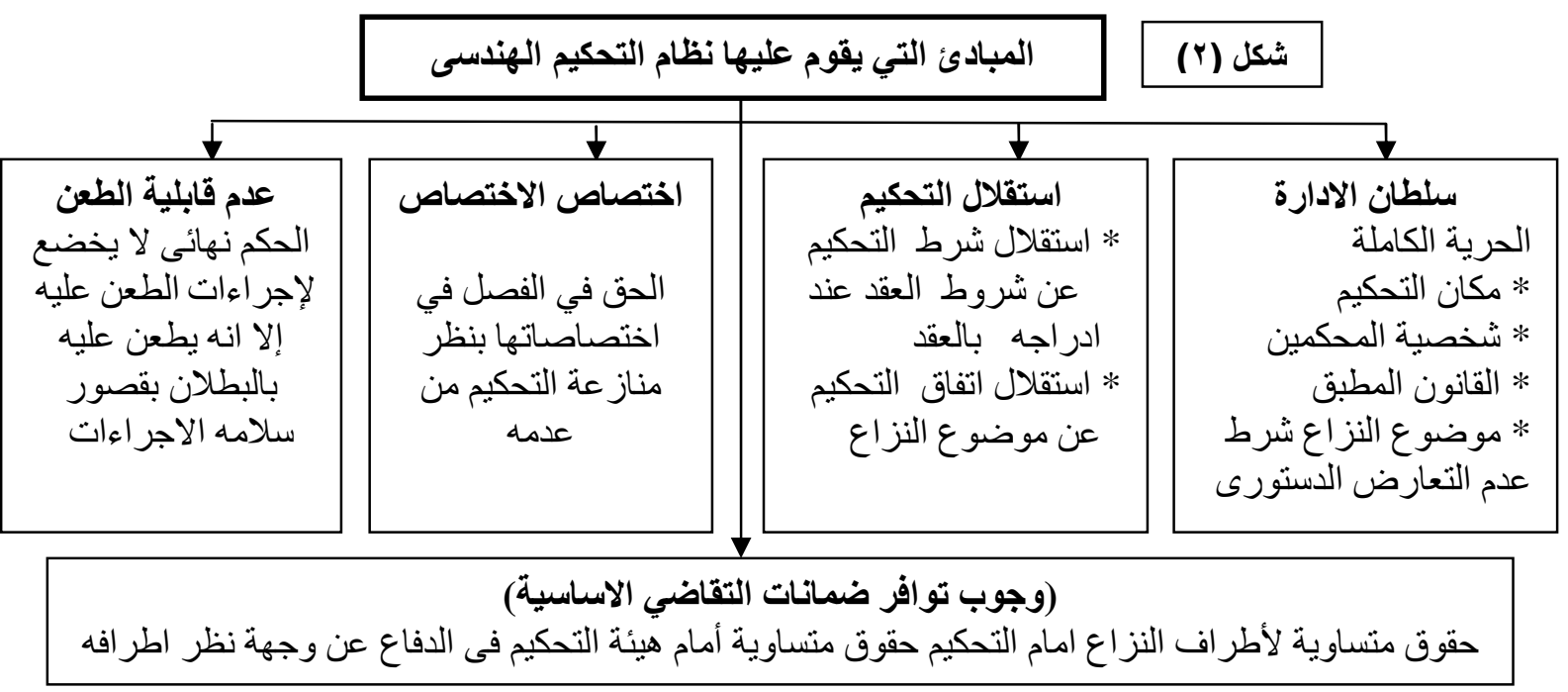

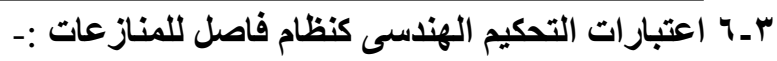

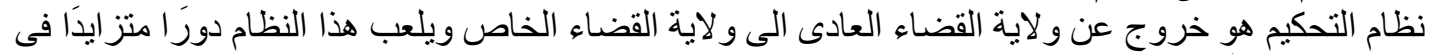

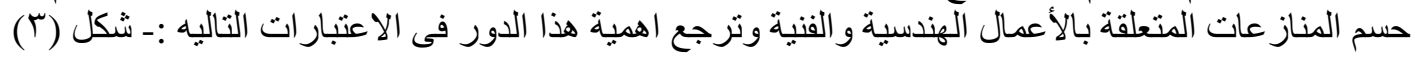

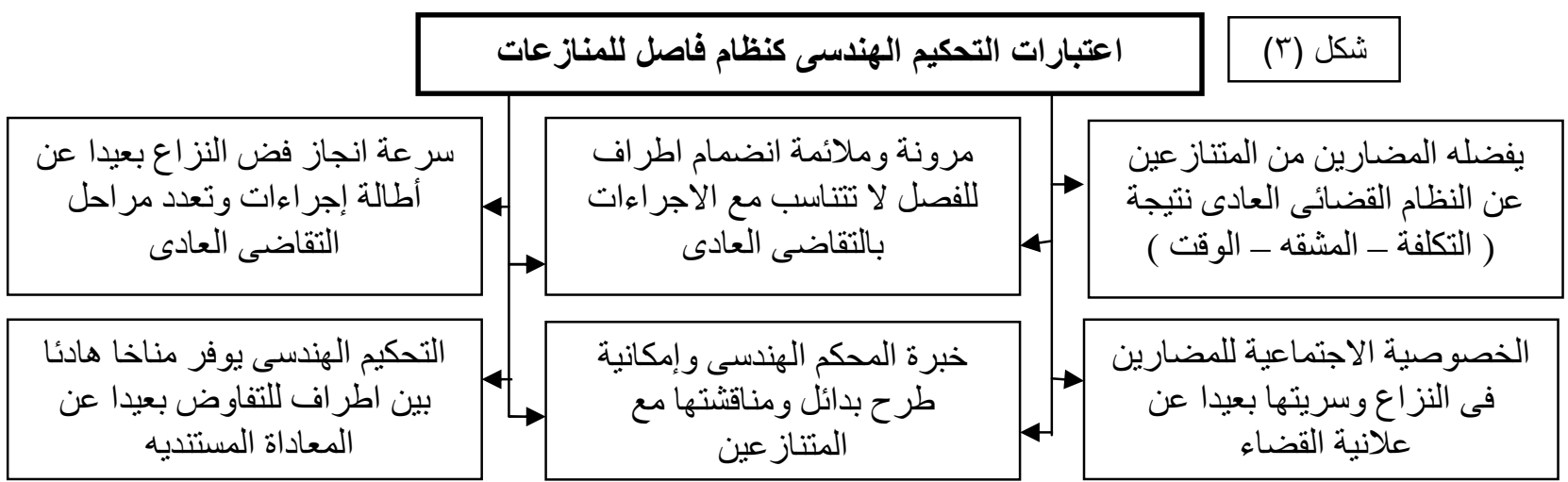




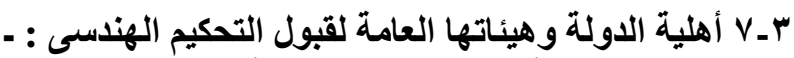

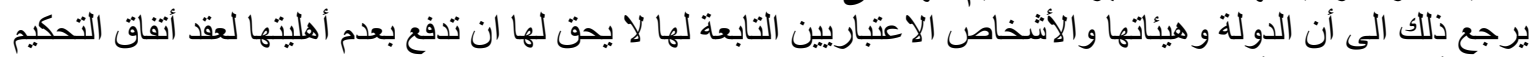

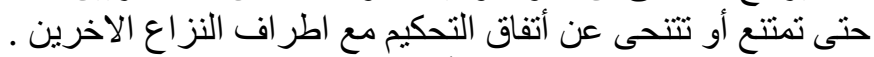

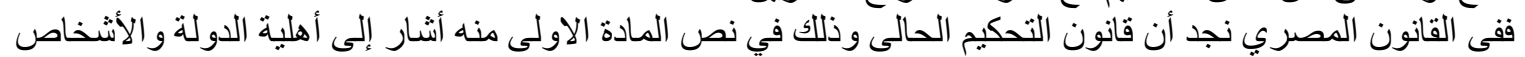

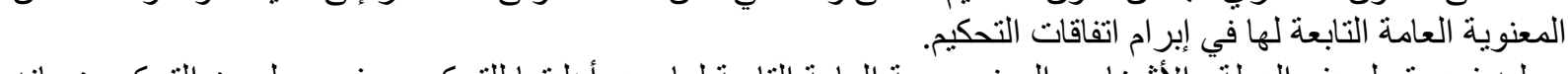

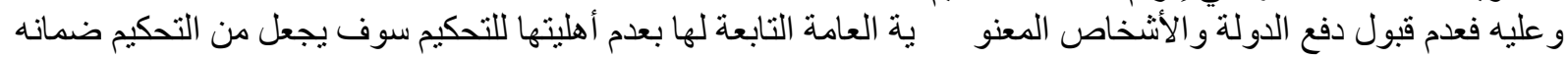

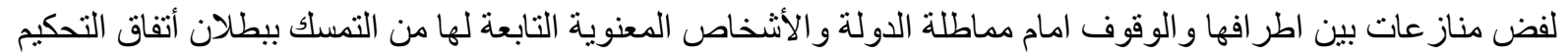

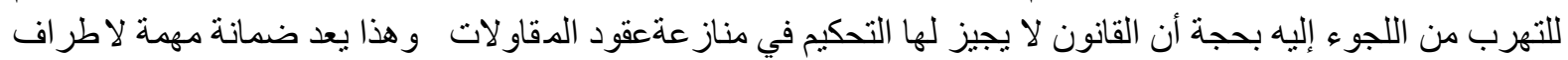

ع ـ قضايا تحكيمية ع ـ القضية التحكيمية الاولى : مقدمة :

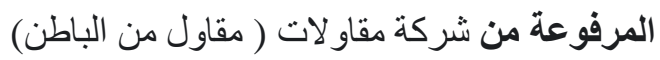

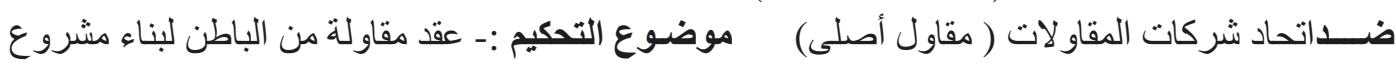

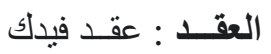

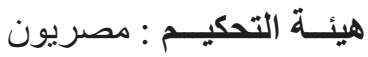
القانون الواجب التطبيق : مصري : التبري القاعدة القانونية : إن وجود أى تسوية فى دعوى تحكيمية القية سابقة بين طرفى التحكيم الحالى لا يمكن تفسيره إلا تفسير ا ضيقا

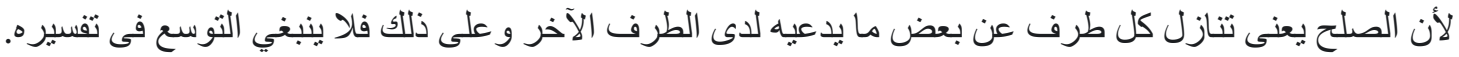

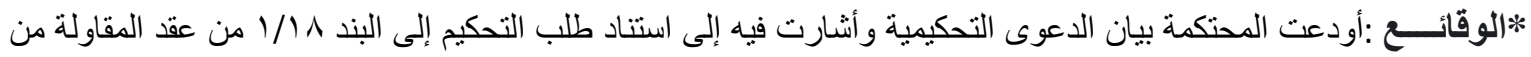

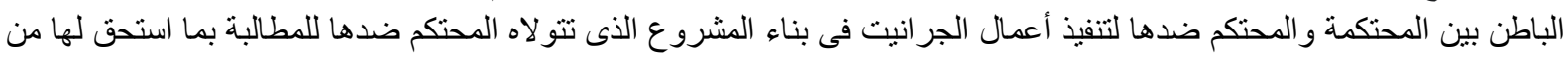

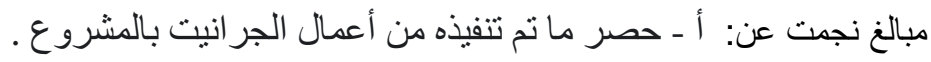

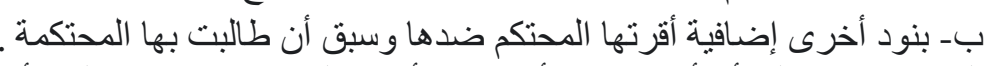

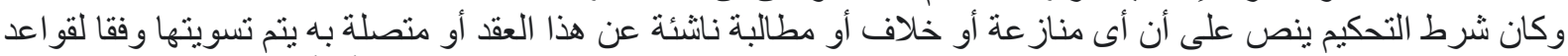

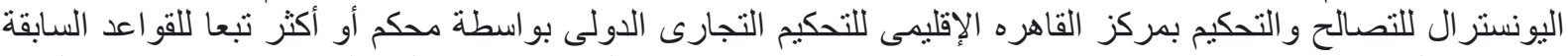

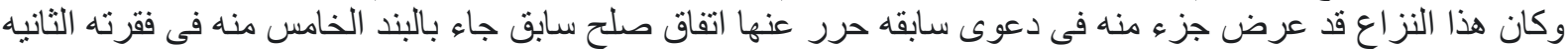

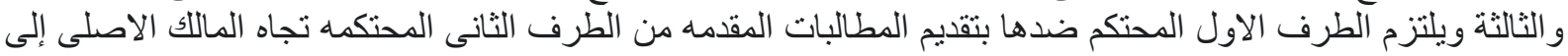

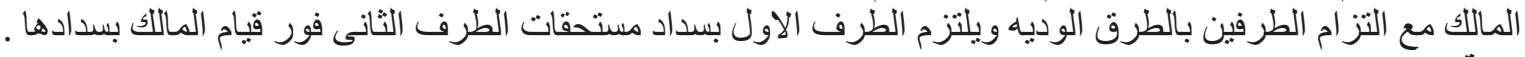

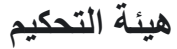

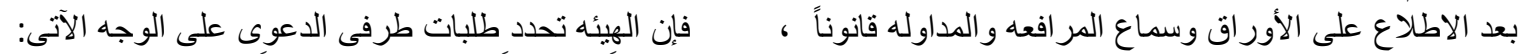

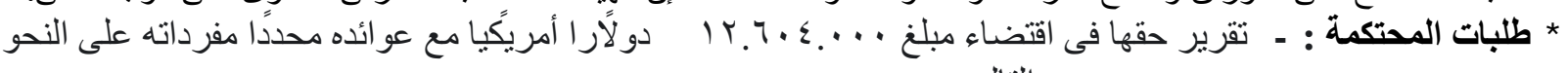
التالى :

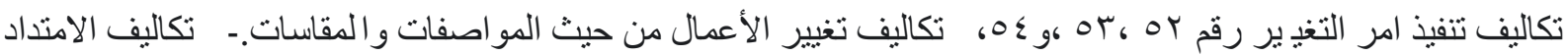

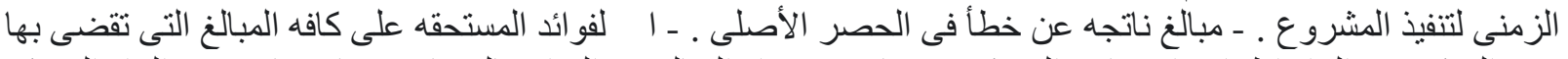

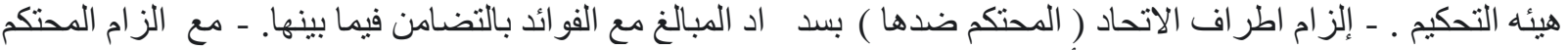

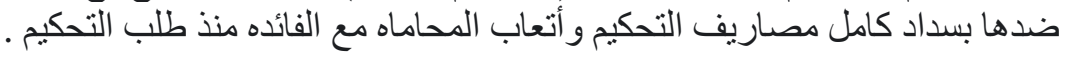

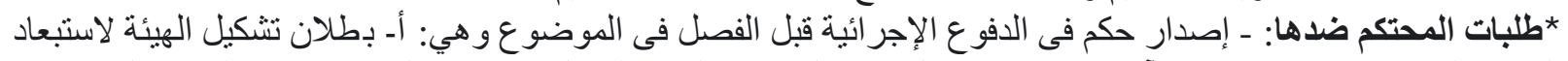

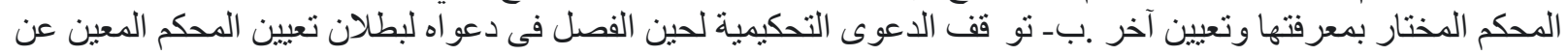

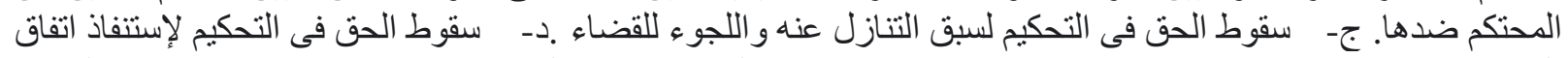

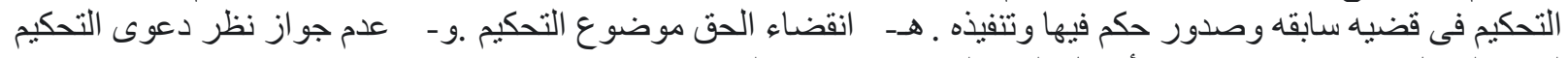

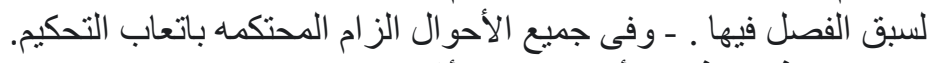
* الفصل فى الدفوع الأجرائيه التى أثثارتها المحتكم ضدها: 1 - بخصوص الافحع الأول والثانى و هما بطلان تشكيل الهيئه لاستيفاء المحكم المختار بمعرفة الاتحاد وتعيين محكماً آخر

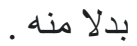

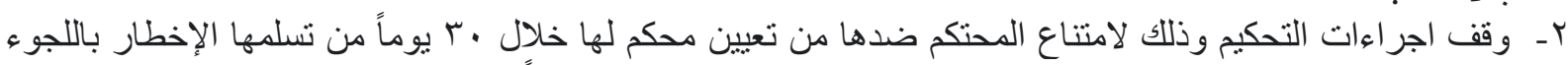

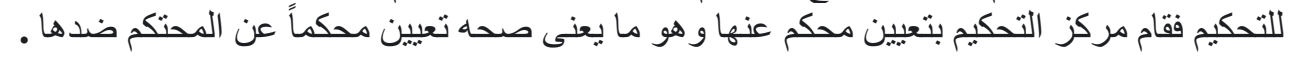

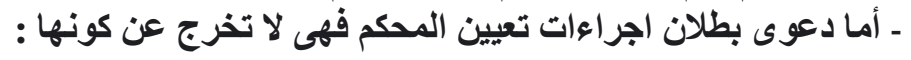




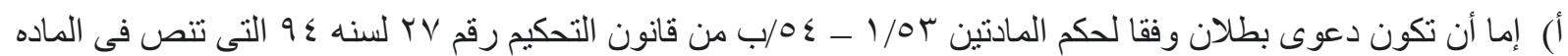

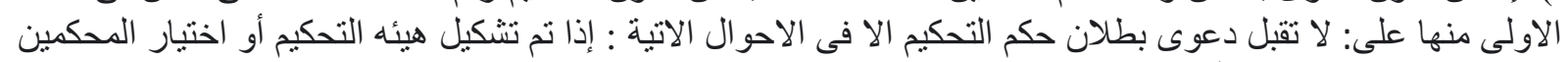

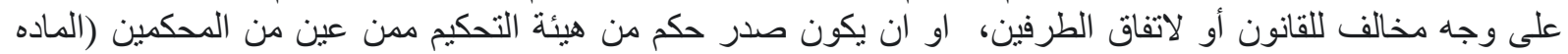

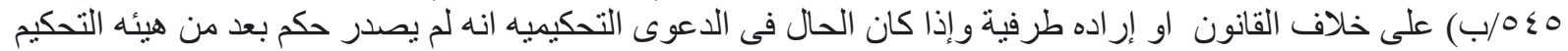

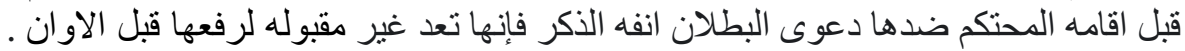

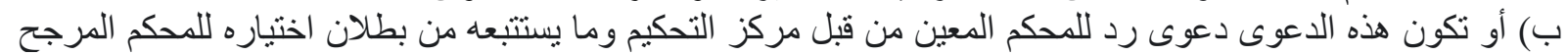

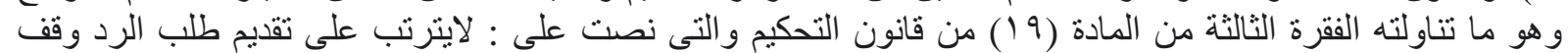

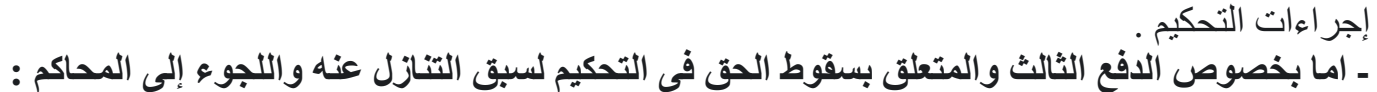

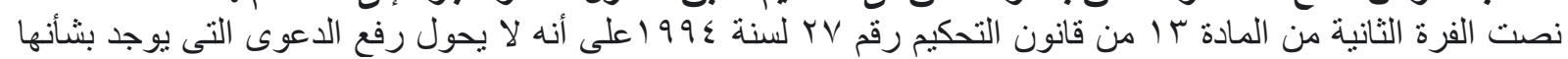

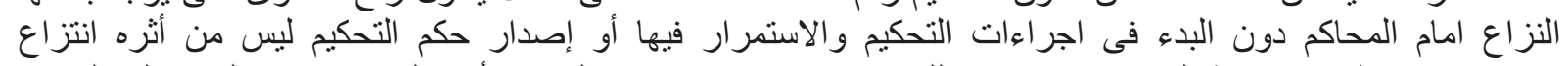

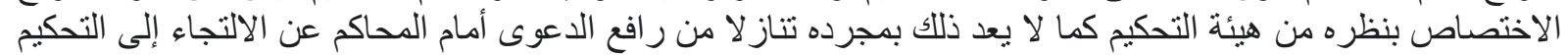

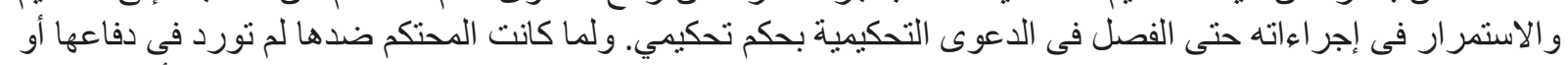

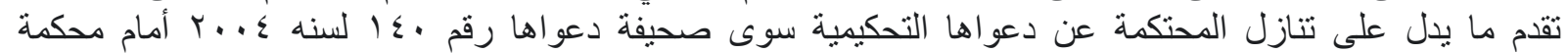

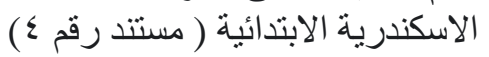

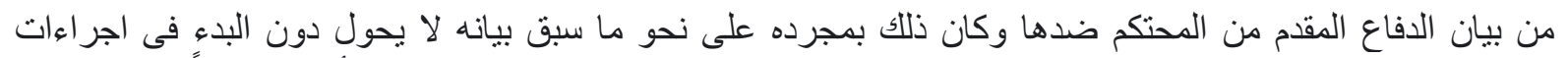

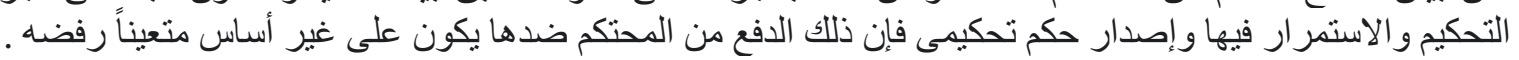

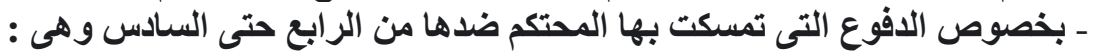

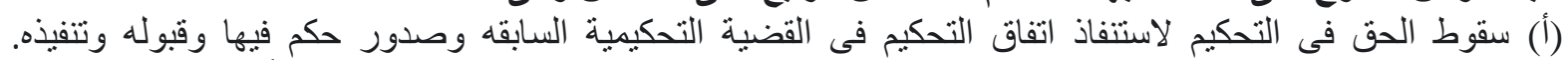

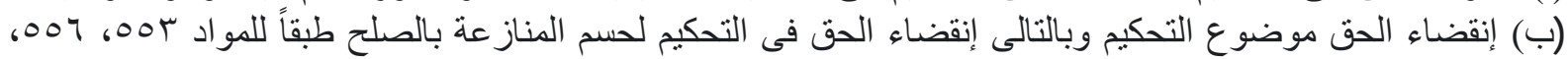

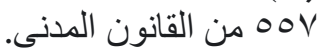

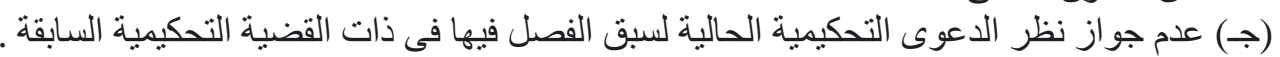

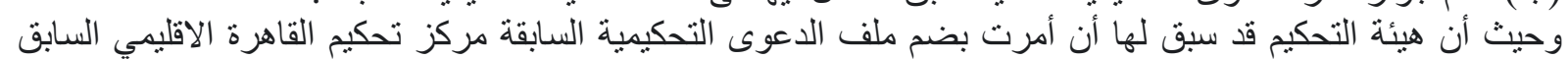

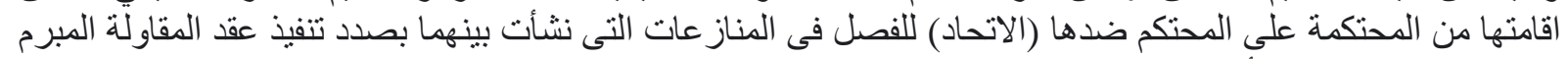

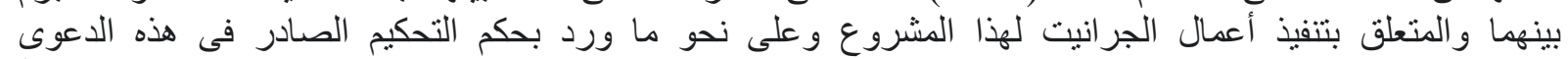

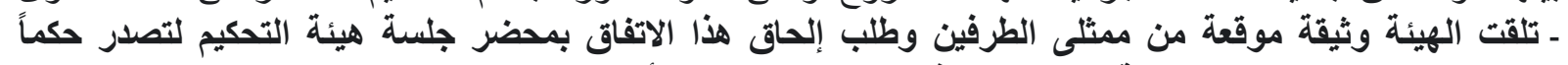

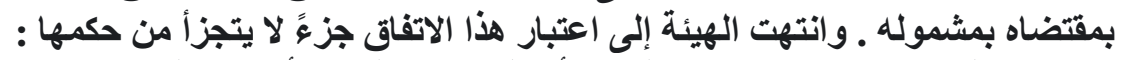

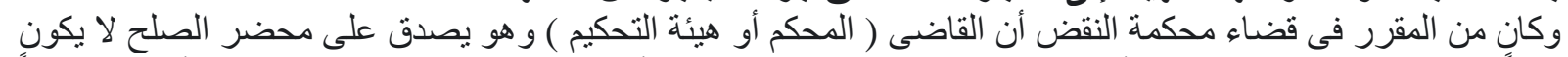

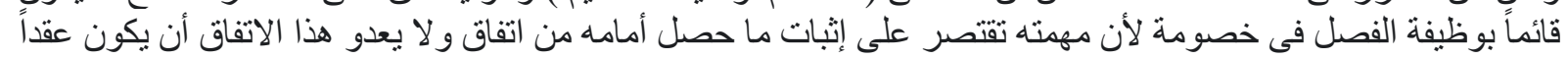

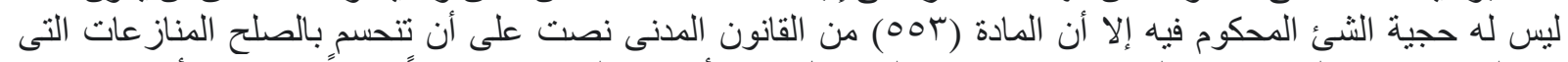

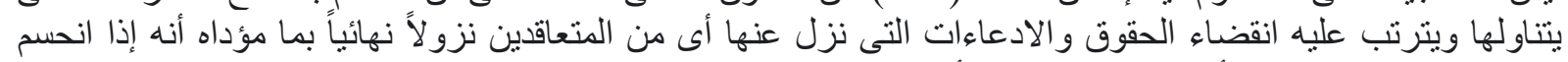

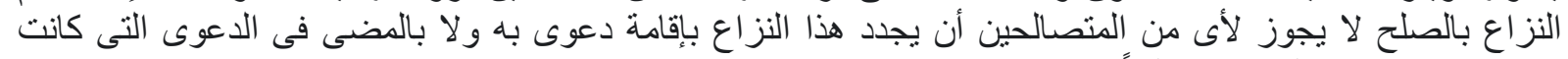

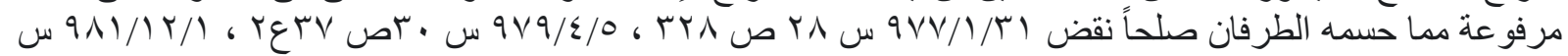

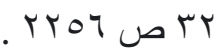

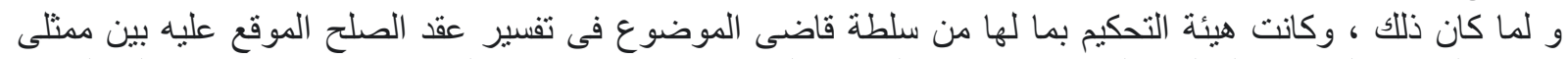

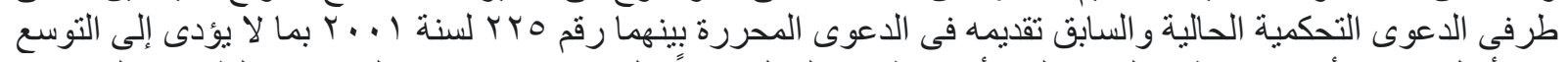

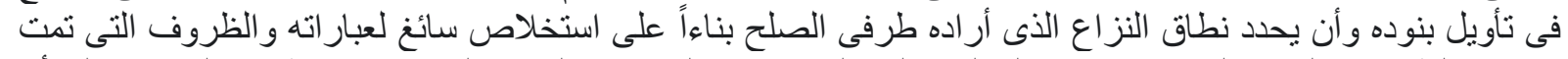

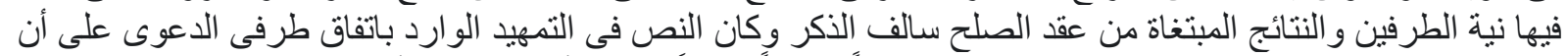

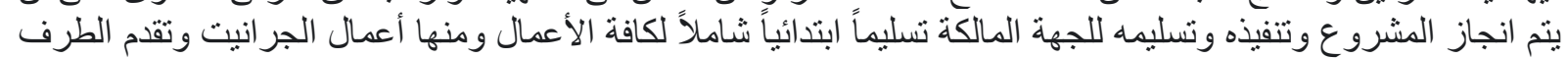

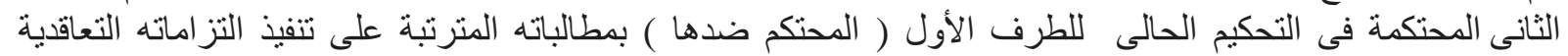

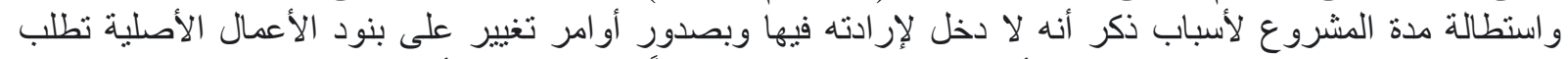

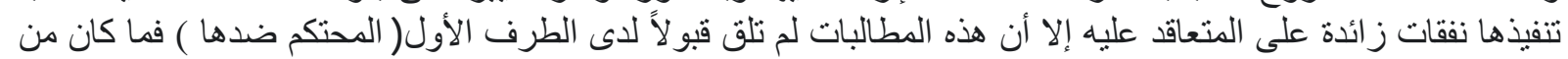

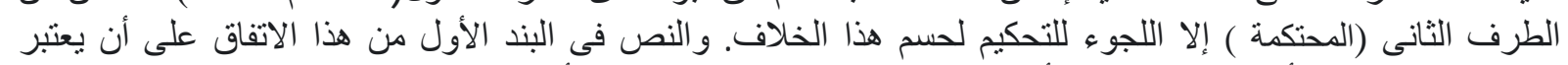

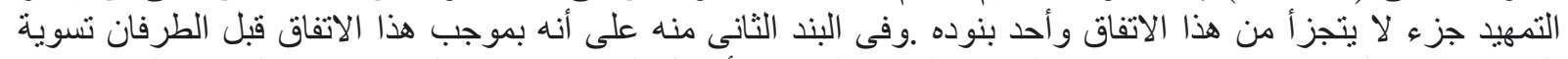

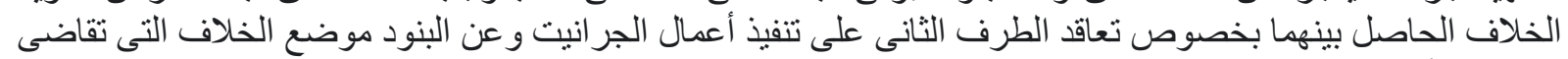

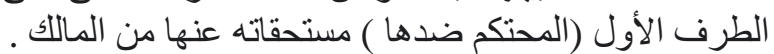

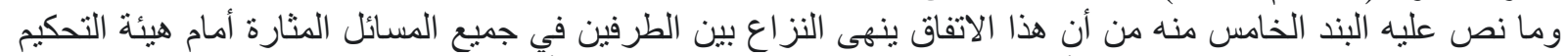
و غير ها من الجهات بحيث لا يجوز لأى من الطرفين مطالبة الطرف الخف الآخر بأى منطلبات نتعلق بشئ من هذه المسائل 


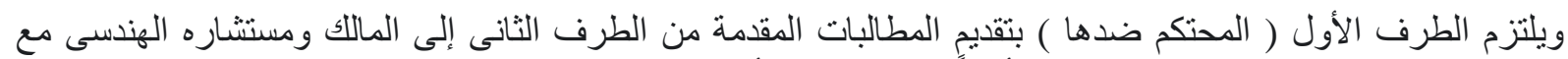

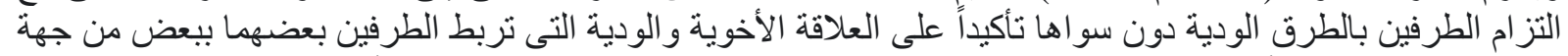

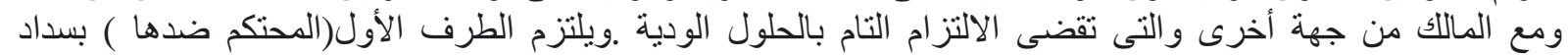

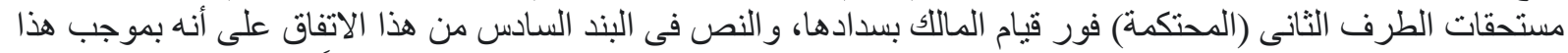

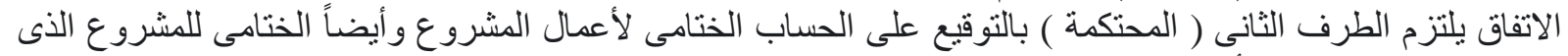

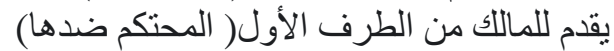
مفاده أولاً: أن موضو اللورع التسوية الودية فى النزاع التهاع التحكيمي السابق باعنباره صلحاً وما سدد عنه من مبالغ من (الاتحاد)

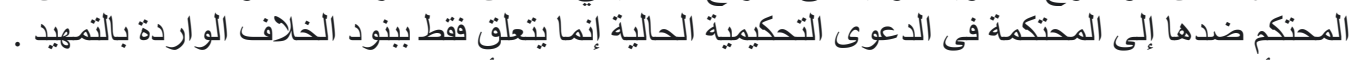

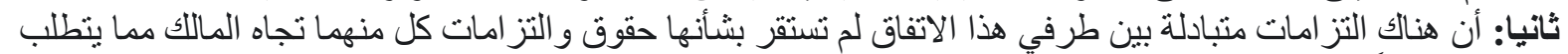

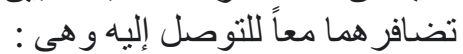

(أ) التزام المحتكم ضدهاً التوصن إنقديم طلبات المحتكمة إلى المالك ومستشاره الهندسى و التز امها بسداد مستحقات المحتكمة فور

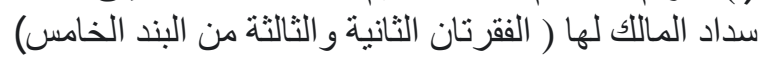

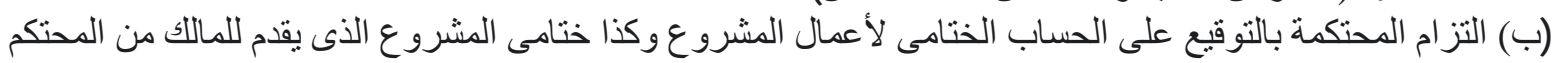
ضدها ( البند السادس. ).

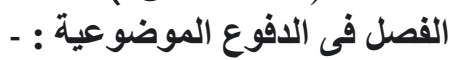

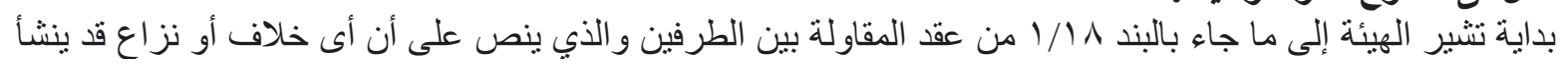

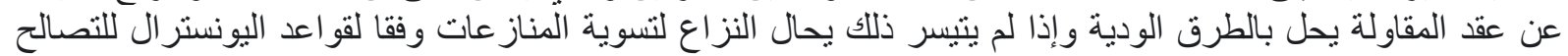

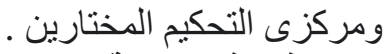

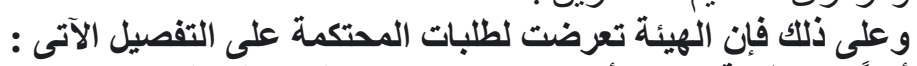

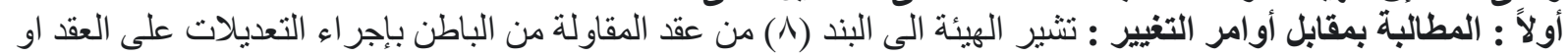

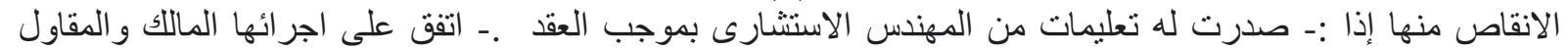

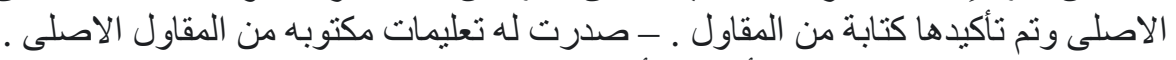

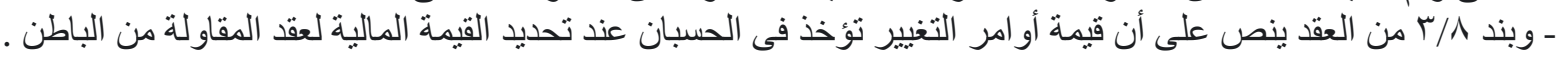

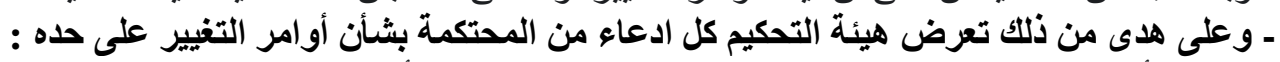

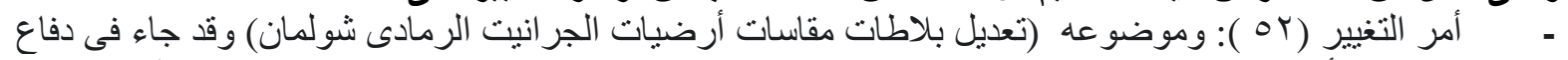

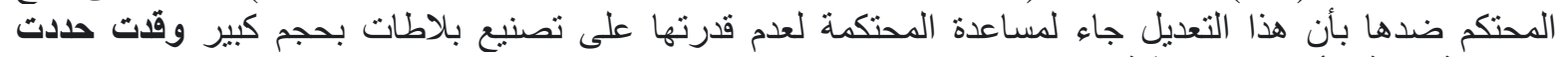

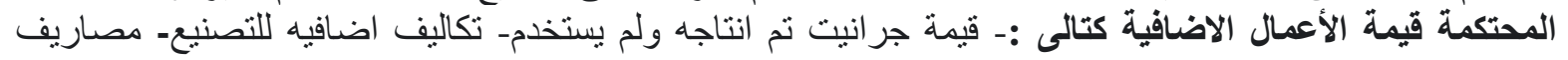

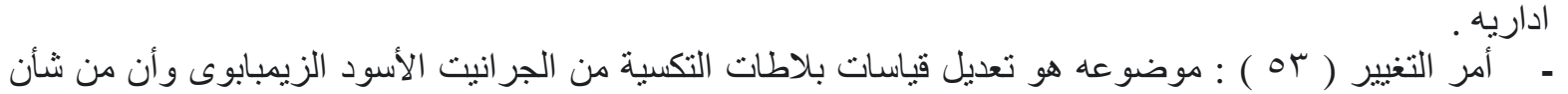

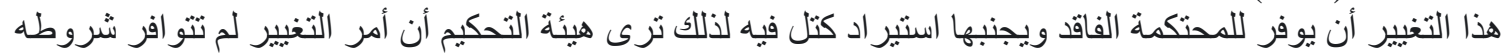
ولذا تقضى الهيئة برفضه.

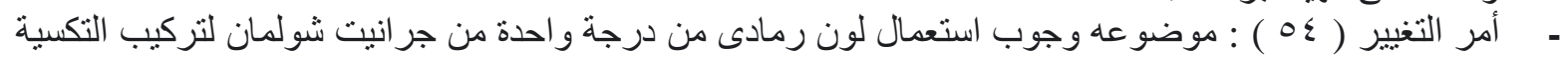

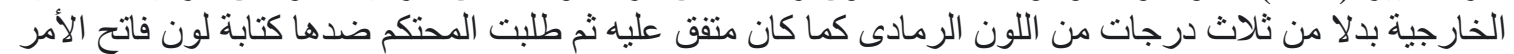

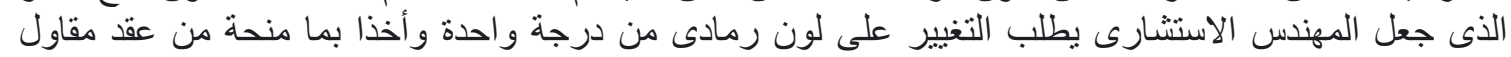

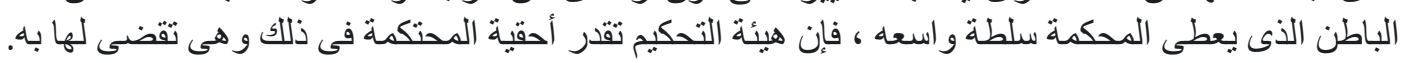

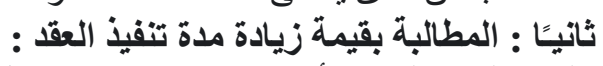

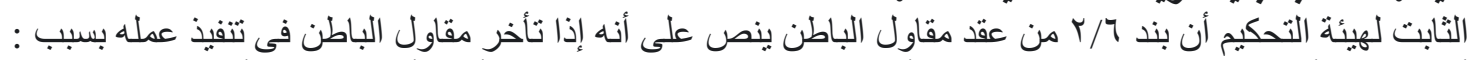

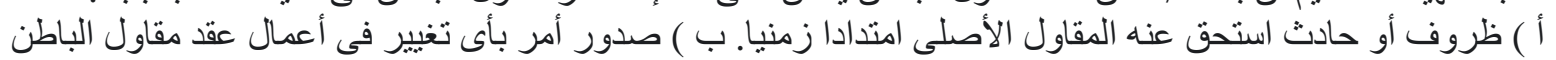

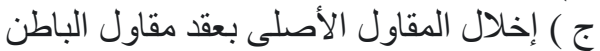

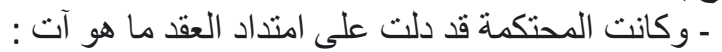

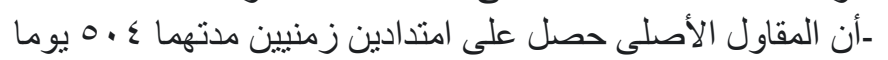

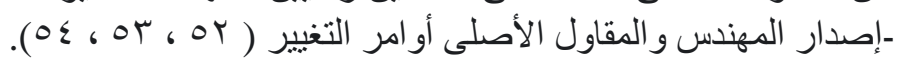

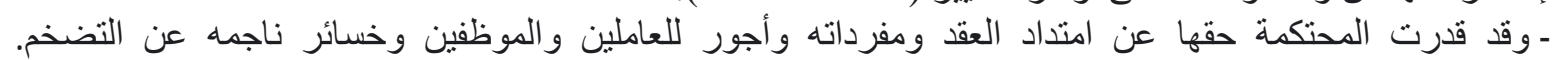

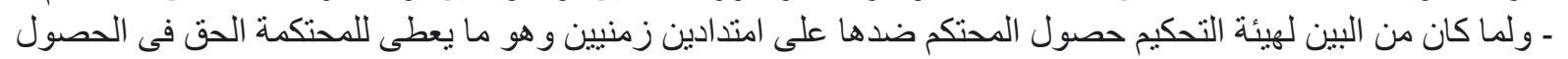

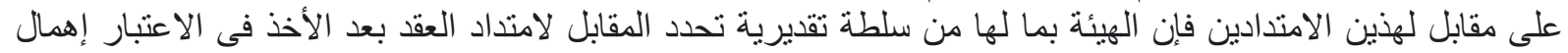

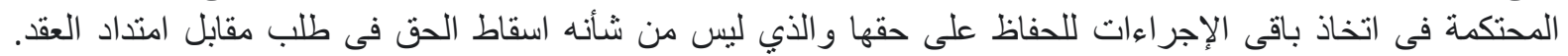

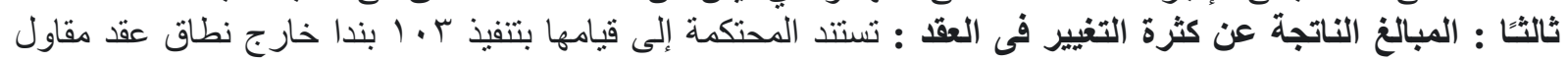


الباطن دون تفصيل لمفرداته أو بيان عناصره حتى تعمل الهيئة سلتطها التقديريه بشأن كل منها مما يثير الثك لاى الهيئة

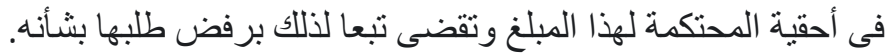

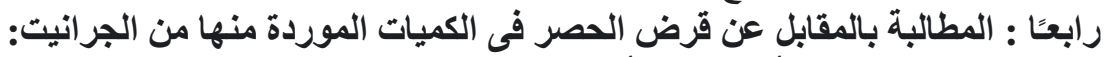

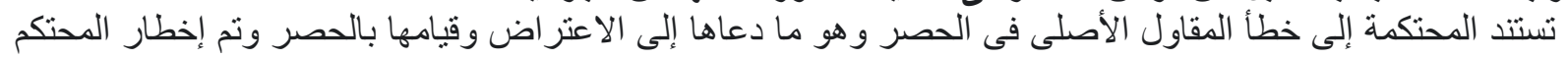

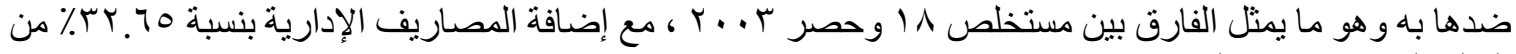

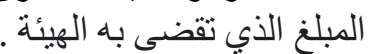

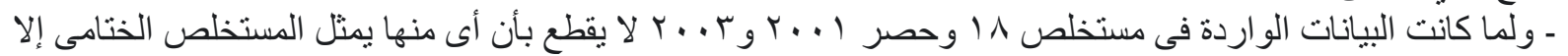

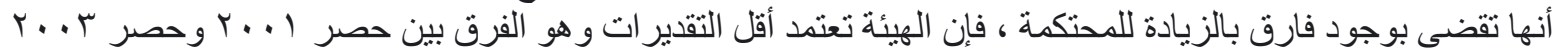

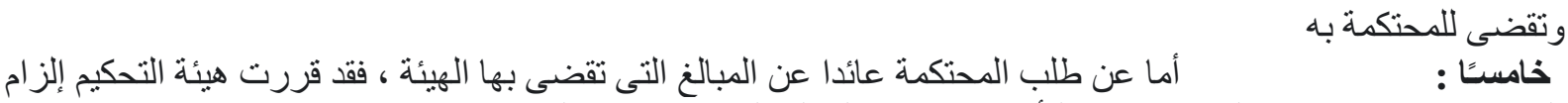

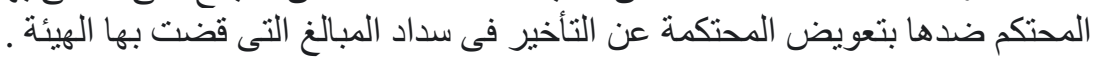

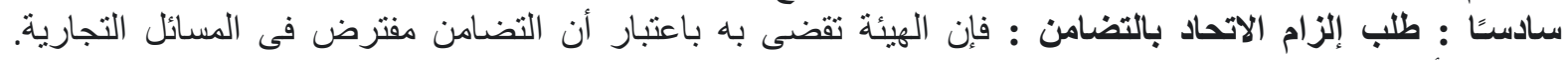

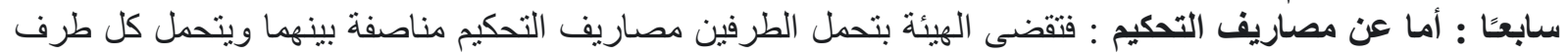

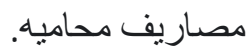

ع ـ بالقضية الثانية : قضية تحكيمية بعنوان ( تقلبات الاسعار وحق المقاول فى زيادة فى الأسعار):

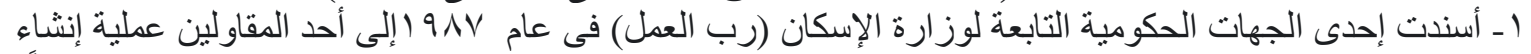

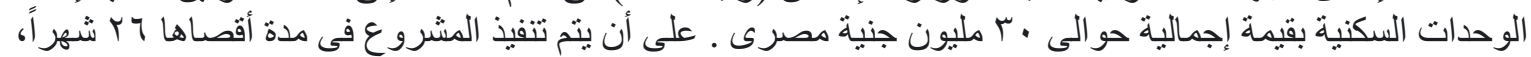

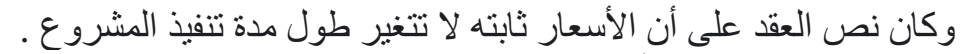

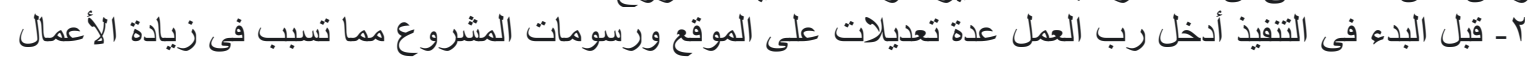

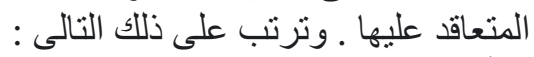

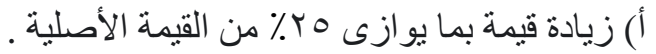

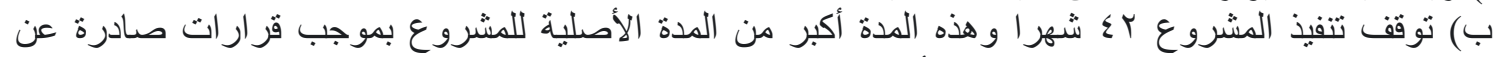

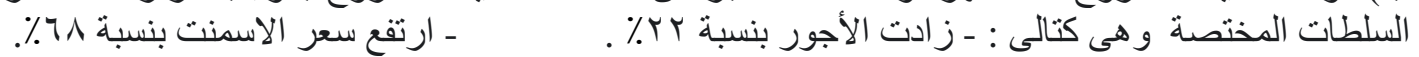

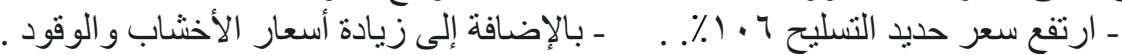

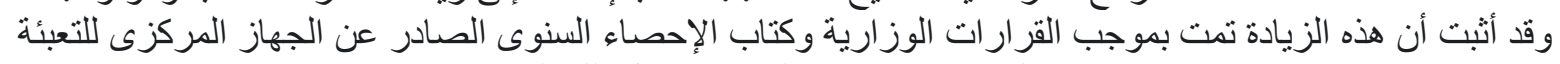

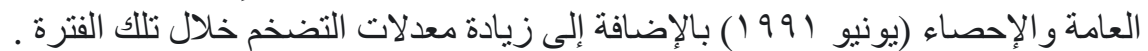

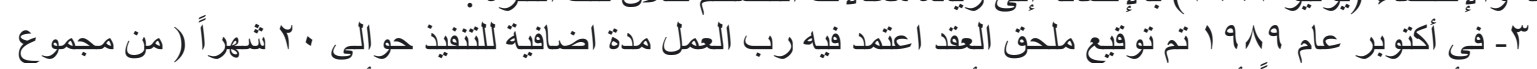

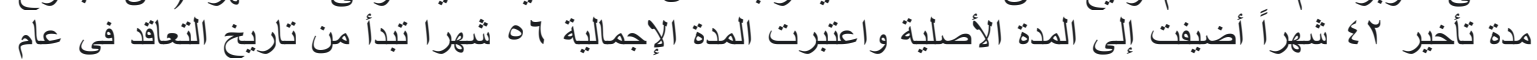

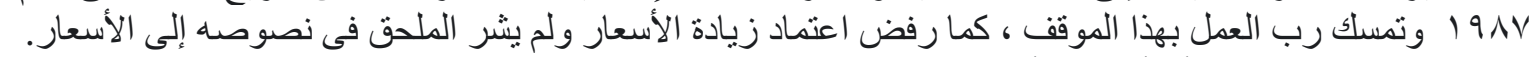

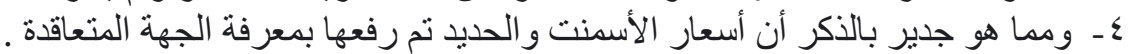

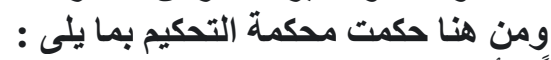

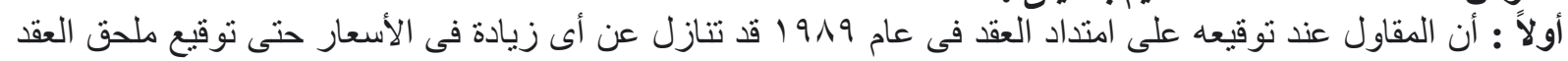

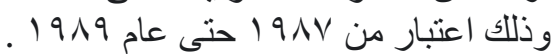

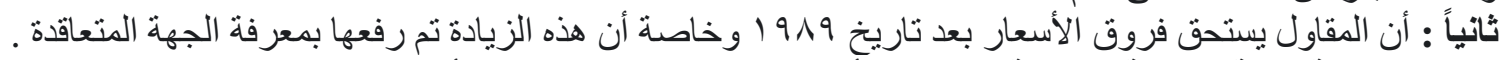

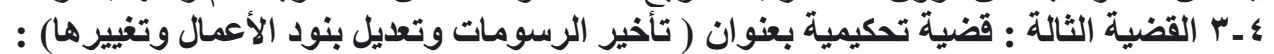

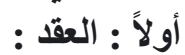

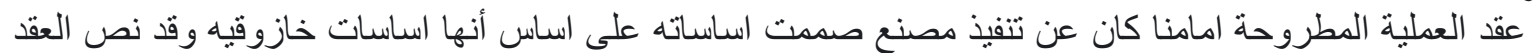

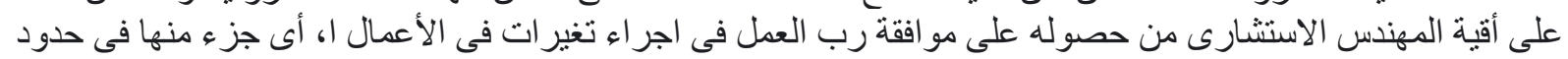

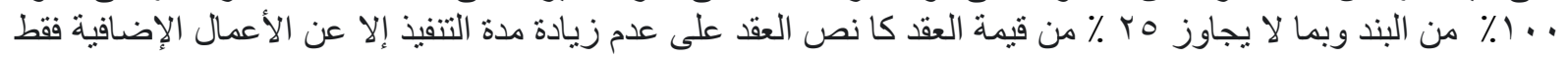

وبنفس نسبة الزيادة أقيمت الأعمال الإضافية بنسبة لقيمة العملية .

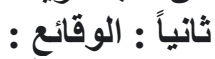

عند تنفيذ الأعمال قام المهندس الأستشارى (وبعد حصوله على موافقة رب العاب العمل) بتعديل الاساسات واستبدالها

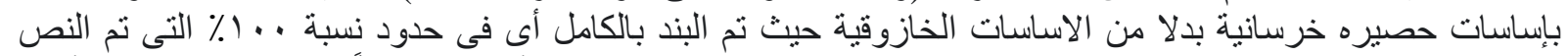

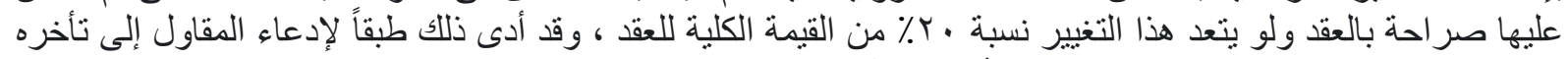

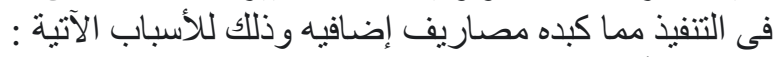

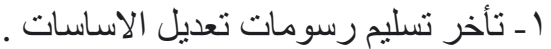

ץ- زيادة كميات الخرسانة وحديد التسليح والنجارة والتبات والحفر والردم نتيجة تغيير الاساسات الى لبشة من الخرسانة المسلحة على أعماق كبيرة ( ليس لهان فئة من التعاقد) . 


$$
\begin{aligned}
& \text { التحكيم الهذسى في فض نزاعات عقود المقاو لات } \\
& \text { كـ ـ تعديل غير متوقع فى امكانيات التنفيذ من ناحية المعدات ـ العمالة ـ المواد ـ ـ العيل }
\end{aligned}
$$

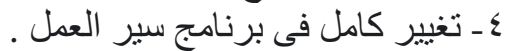

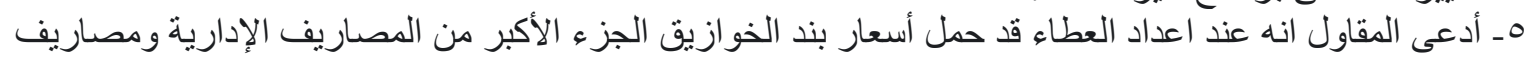

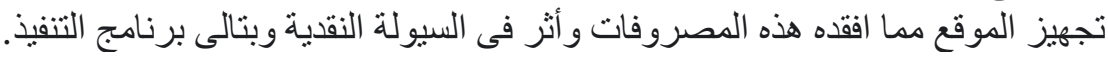

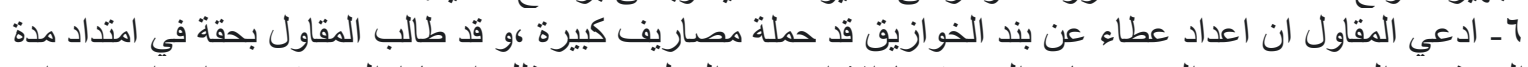

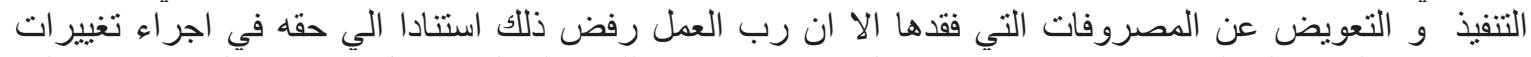

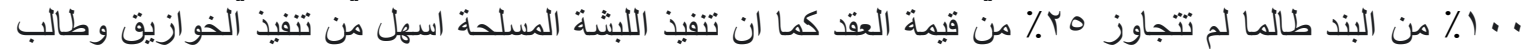

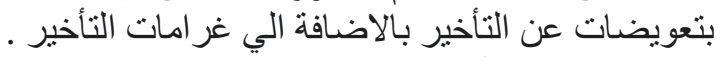

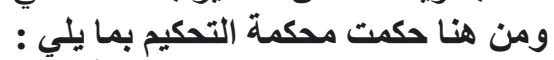

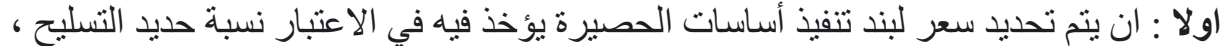

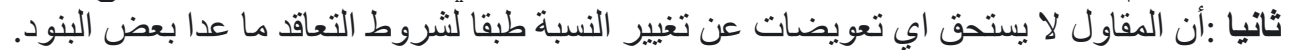
ثالثا :أن المقاول يستحق زيادة في مدة تنفيذ الاعمال و هي تمثل فرق المئل المدة من تاريخ تسليمة الموقع وحتي تسليم رسومات

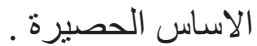

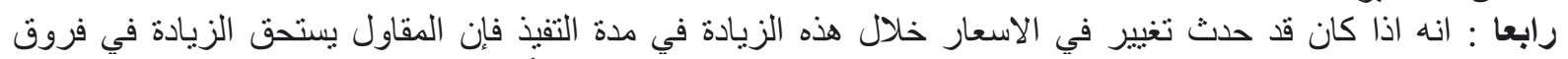

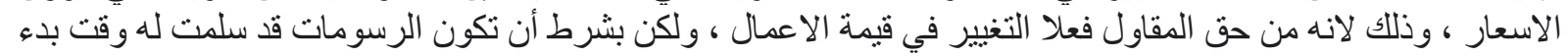

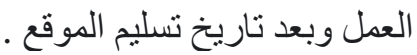

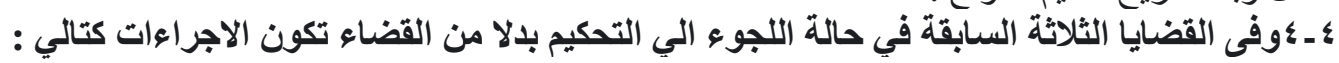

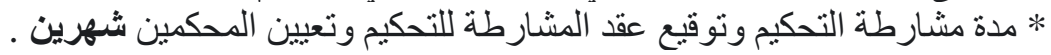

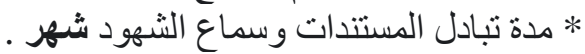

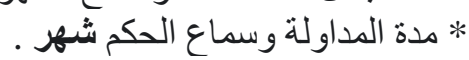

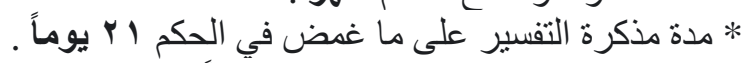

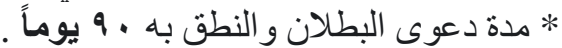

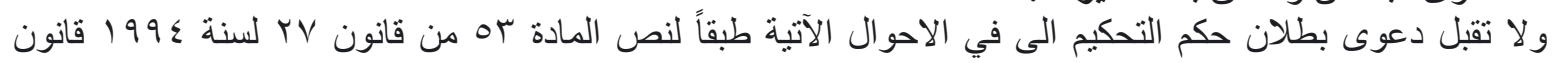

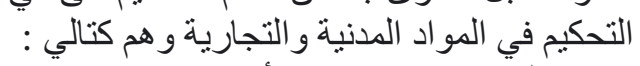

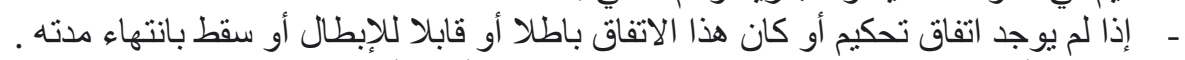

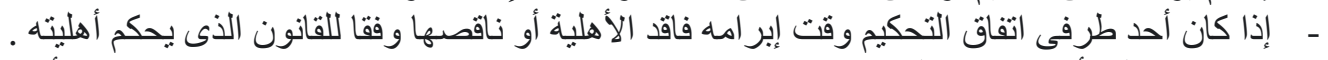

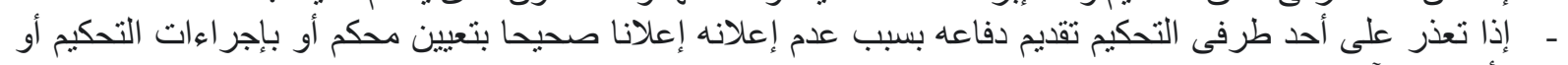

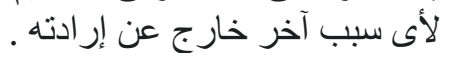

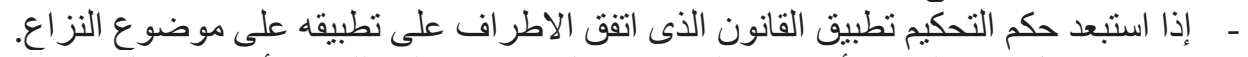

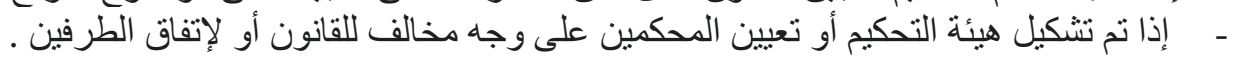

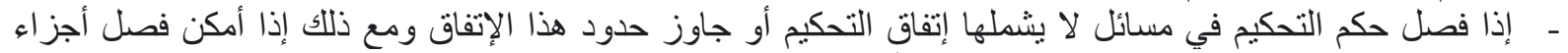

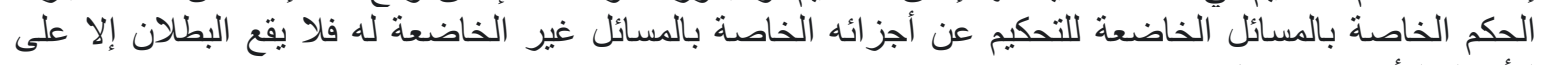

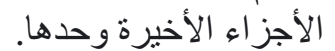
- إذا وقع بطلان في حكم التحكيم أو كانت إجر اءات التحاء التحكيم باطلة بطلاناً أثر في الحكم .

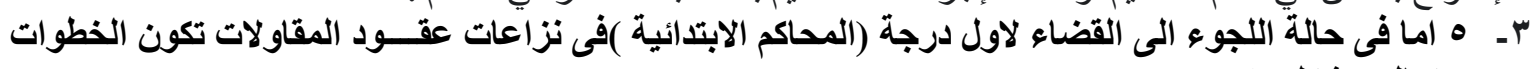

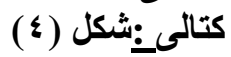




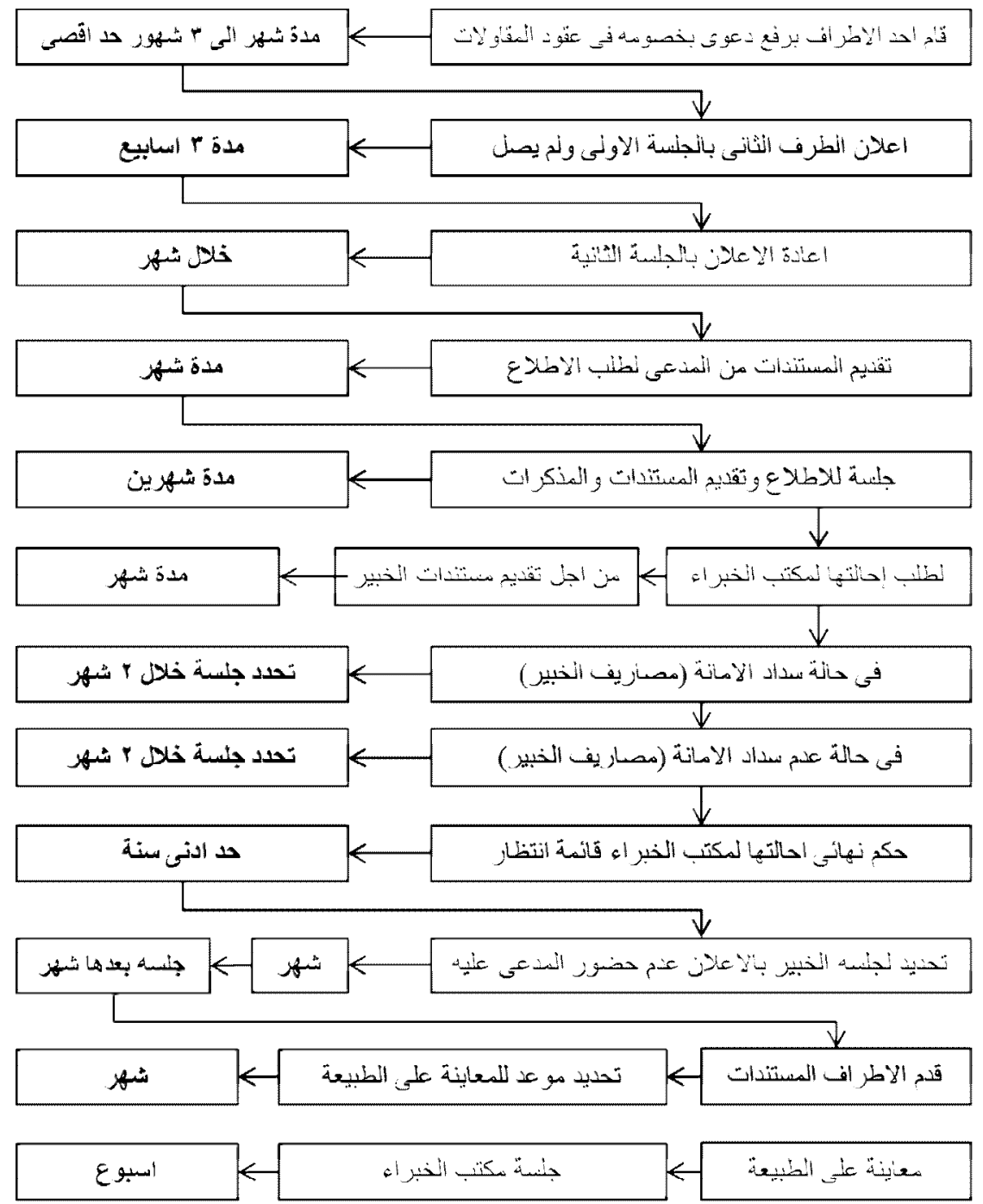

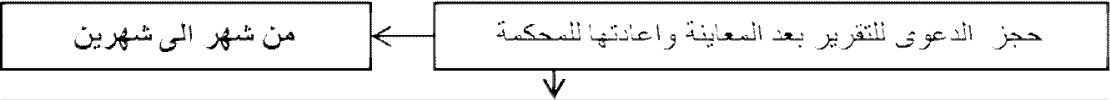

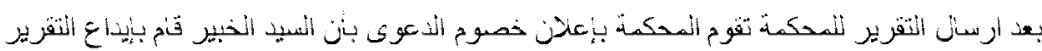

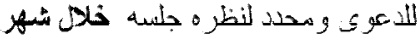

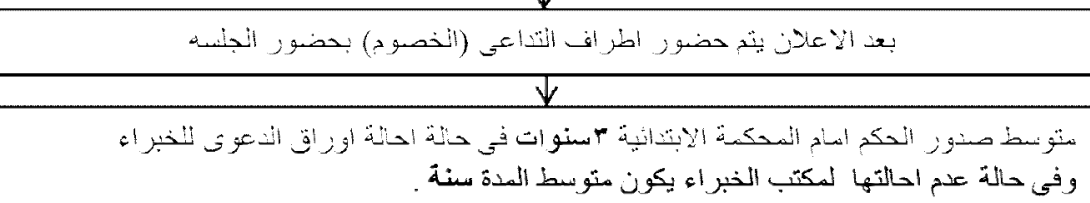

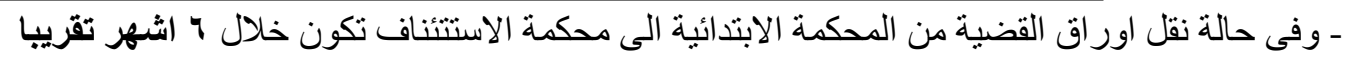

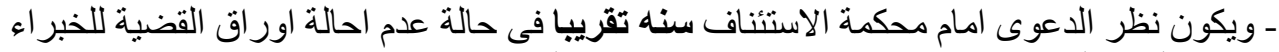

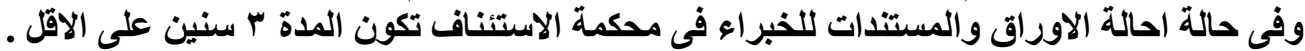

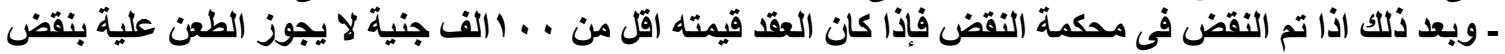

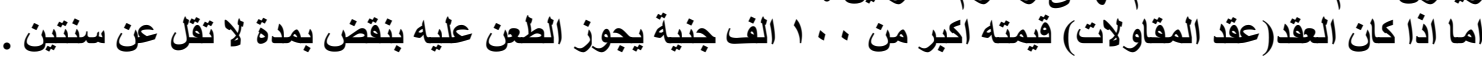

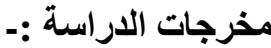

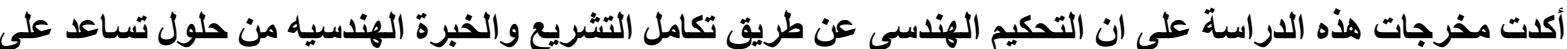

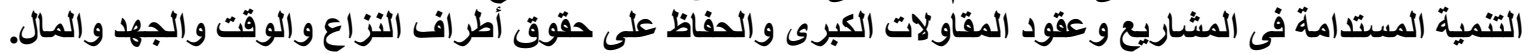




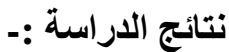

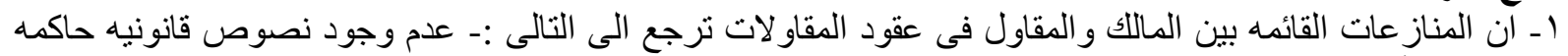

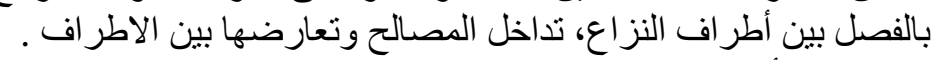

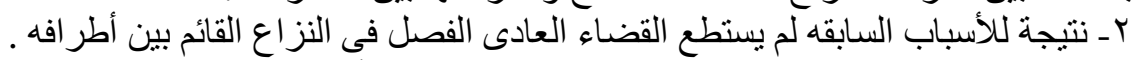

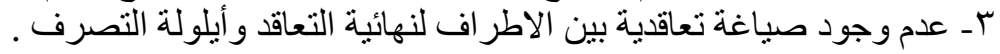

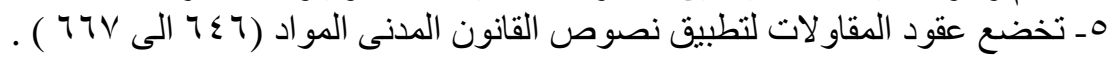

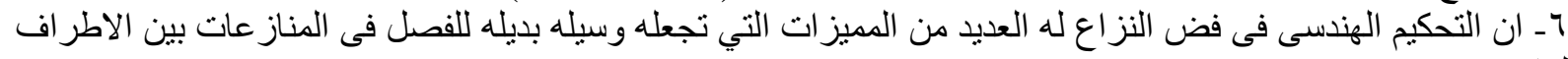

$$
\text { لديه من خبرة هندسيه معماريه و التخطيطية . لمبية }
$$

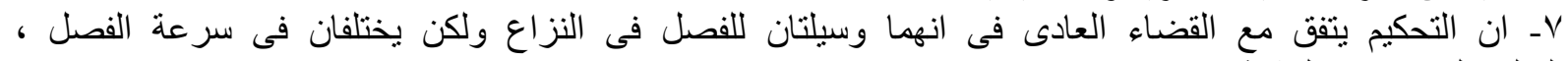

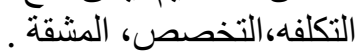

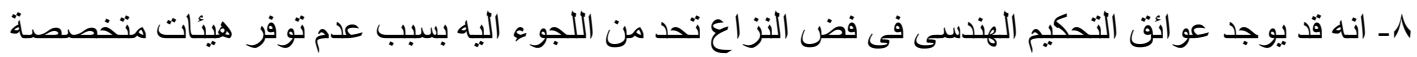

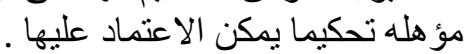

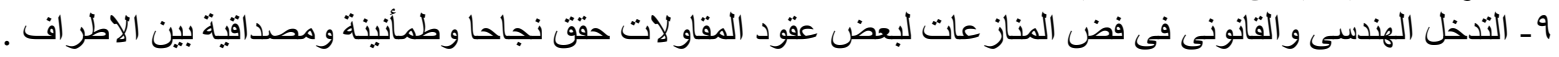

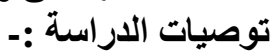

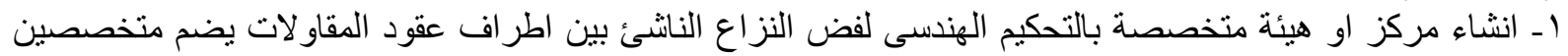

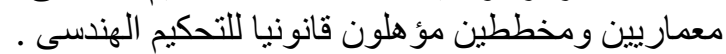
r ـ تأهيل متخصصين ومنين معماريين ومخططين لمهام التحكيم الهندسى لتسوية النز اعات من خلال دور ات تدريييه

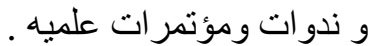

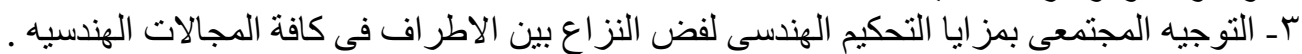

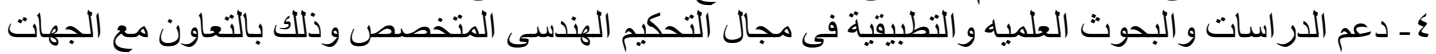

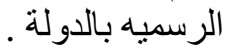

هـ وضع سجلات لقو ائم من وز ارة العدل لمحكمين مؤ هلين هندسيا وقانونيا وتشريعيا للعمل على نشر هذه القوائم

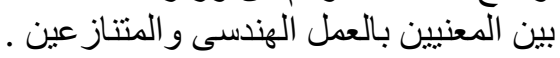

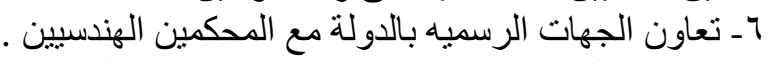

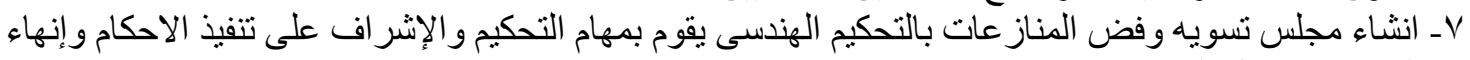

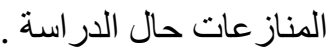

يـ اعداد در اسات تحكيم من قبل المتخصصين كنماذج استرشادية تكون مستوفيه لجو انبها الهندسيه و التشريعية

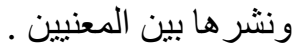

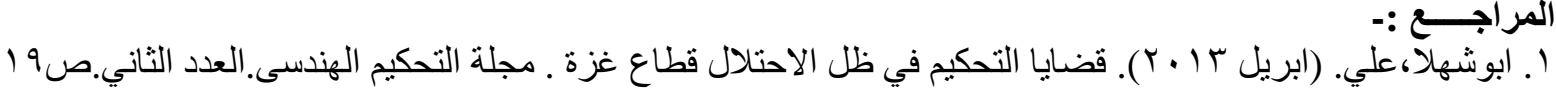

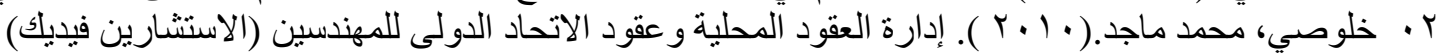

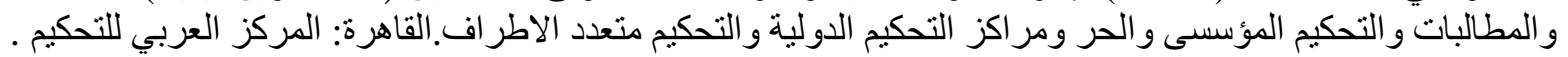

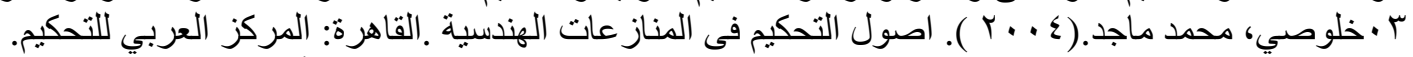

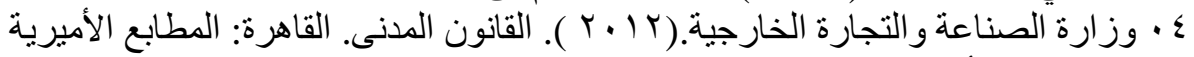

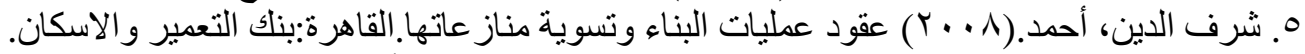

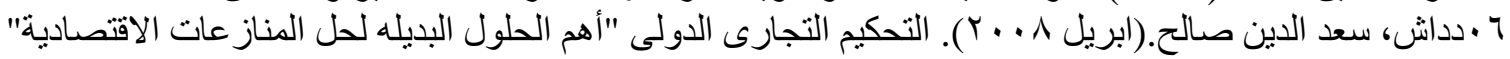

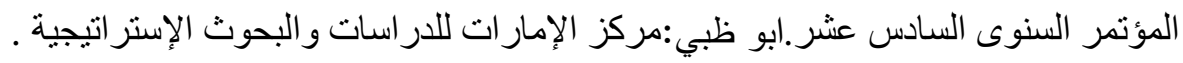

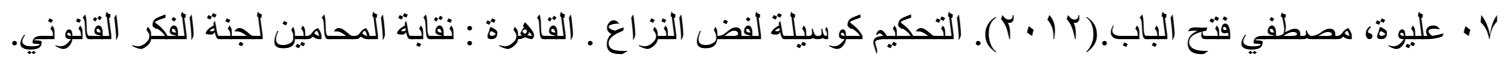

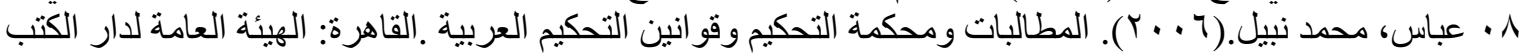
و الوثائق القومية.

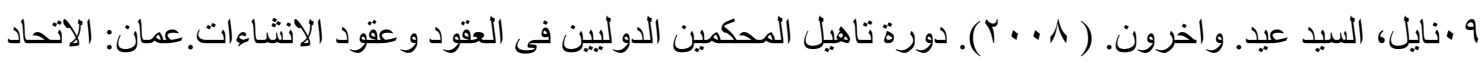

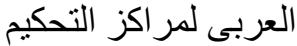

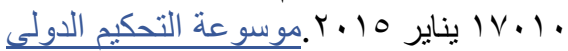

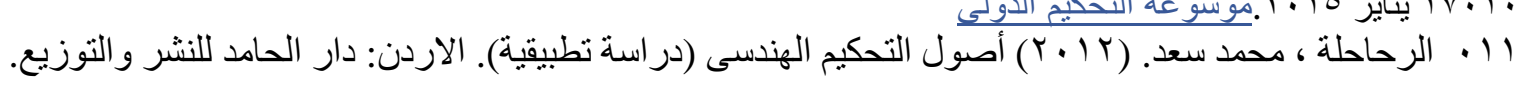

